\title{
The Isolation and Characterization of Mutants of Bacillus subtilis and Bacillus licheniformis with Disturbed Morphology and Cell Division
}

\author{
By H. J. ROGERS, MOYRA MCCONNELL AND I. D. J. BURDETT
}

National Institute for Medical Research, Mill Hill, London, N.W.7

(Accepted for publication 24 December 1969)

SUMMARY

\begin{abstract}
Mutants (rod) have been isolated from one strain of Bacillus subtilis and two of $B$. licheniformis after treatment with I-methyl-3-nitro-I-nitrosoguanidine, by replica plating from media containing $0.8 \mathrm{M}-\mathrm{NaCl}$ to media of low salt content. When grown on the latter media these mutants appear as groups or strings of coccal bodies which, when examined in section under the electron microscope, show gross distortions in their walls and membranes; septum formation is greatly disorganized. When grown in media containing 0.8 to $\mathrm{I} \cdot 0 \mathrm{M}-\mathrm{NaCl}$, or $\mathrm{KCl}$, or ample supplies of organic nitrogen, considerable correction of the morphology of one class of these mutants occurs. The other class of mutants is not changed to rods by growth in media of high salt content but is so changed by growth on rich media containing yeast extract. All the mutants revert to the parent type, but at very different rates. The physiological characteristics of the mutants and the parents are in most respects identical.
\end{abstract}

\section{INTRODUCTION}

The chemical structure and biosynthesis of the component polymers in bacterial cell walls are now well documented (Rogers \& Perkins, 1968). Little is yet known about the regulatory relationships between wall and membrane formation which control replication of shape during cell division. A reasonable simile to illustrate the present state of knowledge about the interrelationship would be to regard it as a conversation between the membranes, the wall and the DNA. The DNA, at least in Bacillus, appears to be attached to the sac of the mesosomal membrane (Ryter, I968), which in turn appears likely to be involved in the division of the DNA (Jacob, Ryter \& Cuzin, 1966; Ryter, I968). Meanwhile the membranes have fixed to them many of the enzymes and the intermediate carrier concerned with the synthesis of the wall polymers (Rogers \& Perkins, 1968). The mucopeptide in the wall presumably defines the shape of the micro-organisms during growth and its inward growth into the septum divides the cell into two siblings. Disturbance in this conversation by lesions affecting either wall or membrane synthesis would be expected to lead to upsets in the morphology of the cell and in the division process. In one of the extreme forms of disturbance of wall synthesis, the wall is not formed at all by Gram-positive species, and then the shape and the normal division process are lost; such is the case with multiplying protoplasts (Landman \& Halle, I963; Landman, Ryter \& Fréhel, 1968) and with L-forms. Failure to initiate DNA synthesis, on the other hand, also leads to filaments and other morphological disturbances (Mendelson \& Gross, 1967; Hirota, Ryter \& Jacob, 1968). 
One way to select mutants capable of growing with weakened walls is to look for bacteria that are dependent on high concentrations of suitable substances, such as sucrose, in the growth medium. These substances act as osmotic supports for bacteria with inadequate wall structures. Mangiarotti, Apirion \& Schlessinger (I966) isolated mutants of Escherichia coli dependent upon a high concentration of sucrose, and of five such mutants reported four of which grew as filaments without sucrose, whilst one was absolutely dependent upon the presence of sucrose in the growth medium. For one of the mutants growing as a filament, sucrose could be replaced by D-alanine, an essential component of the mucopeptide in the wall.

In the present work mutants of Bacillus subtilis and B. licheniformis have been selected which are partially dependent on the presence of high concentrations in the growth medium of sodium chloride rather than sucrose. Sucrose was unsatisfactory because of the nature of the colonies produced on media containing high concentrations of this carbohydrate. These mutants have a disturbed gross morphology which can be corrected to a large extent by the presence in the growth medium of low concentrations of certain amino acids and high concentrations of salts, or by rather high concentrations of the amino acids alone. One of these mutants examined in detail has a relatively uncrosslinked wall (Rogers, McConnell \& Hughes, to be published), and examination of sections with the electron microscope shows that the organization of the membranes and division septa is greatly disturbed. The distribution of DNA also would seem to be abnormal. These disturbances in ultrastructure can be corrected by the same agents as those which correct the gross morphology.

A brief report on these mutants (naming them rod mutants) has already appeared (Rogers, McConnell \& Burdett, I968). Whilst preparing this paper a brief report on a temperature-sensitive mutant of Bacillus subtilis with a similar grossly disturbed morphology has been published (Boylan \& Mendelson, 1969).

\section{METHODS}

Micro-organisms. Bacillus subtilis 168 trp, B. licheniformis 9945 A met cap, B. licheniformis $9945 \mathrm{~A}$ ade cap and $B$. licheniformis 6346 lys were kept as spore suspensions in water at $0^{\circ}$, except the latter strain, which was kept dried by the Stamp (1947) method. These suspensions were revived by inoculation into Penassay broth $+0.5 \%$ glucose contained in a conical flask five times the volume of the broth, and incubation at $35^{\circ}$ overnight without shaking. This culture was then inoculated into a further volume of the broth also contained in a conical flask of the same relative size. This flask was shaken at $35^{\circ}$ until the culture reached about the middle of the exponential phase of growth.

Treatment with mutagen. The exponentially growing cultures were centrifuged down and the bacteria were immediately suspended in $0 . \mathrm{I} \mathrm{M}-\mathrm{NaK}$ phosphate buffer $(\mathrm{pH} \mathrm{6.5)}$ at $\mathrm{I} \mathrm{mg}$. dry weight $/ \mathrm{ml}$. as determined by optical density. This suspension was treated with I-methyl-3-nitro-I-nitrosoguanidine at $35^{\circ}$ with aeration until about $99 \%$ of the micro-organisms had been killed. The concentration of mutagen was adjusted to give the required killing within 30 to $60 \mathrm{~min}$. For Bacillus subtilis I68 trp this was $0.02 \%$; for $B$. licheniformis $9945 \mathrm{~A}, 0.04 \%$; for $B$. licheniformis $6346,0.002 \%$. The bacteria were then centrifuged down, suspended in Penassay broth of ten times the volume of the original, and incubated at $35^{\circ}$ with shaking for 3 to $4 \mathrm{hr}$.

Isolation of mutants. The mutagen-treated culture was plated on the following 
medium containing $0.8 \mathrm{M}-\mathrm{NaCl}$ : $\mathrm{FeCl}_{2}, 0.46 \mathrm{mg}$.; $\mathrm{NH}_{4} \mathrm{Cl}, 0.535 \mathrm{~g}$.; $\mathrm{KH}_{2} \mathrm{PO}_{4}, 0.068 \mathrm{~g}$; $\mathrm{Na}_{2} \mathrm{SO}_{4}, 0.106$ g.; $\mathrm{NH}_{4} \mathrm{NO}_{3}, 0.096$ g.; $\mathrm{MgCl}_{2}, 0.004 \mathrm{~g}$.; $\mathrm{MnCl}_{2}, 0.013$ g.; Casamino acids, I g.; NaCl, $46 \cdot 8 \mathrm{~g}$. This solution was adjusted to I 1. with distilled water. It was solidified with $\mathrm{I} \cdot 5 \%$ agar and sterilized. Glucose solution, sufficient to give final concentration of $0.5 \%$ and the appropriate growth factors to satisfy auxotrophic requirements were added before pouring plates. The mutagen-treated culture was spread so that each plate would grow about 100 to 200 colonies after 2 days at $35^{\circ}$. The growth on the plates was replicated on to the same medium but not containing $0.8 \mathrm{M}$-sodium chloride; these plates were incubated for I day at $35^{\circ}$. Colonies were then picked which grew on the plate containing sodium chloride; these colonies either did not grow on the plate without the salt, or grew as very small colonies as compared with the remainder.

The isolations were all tested for their appropriate auxotrophic requirements and were streaked several times on the $0.1 \%$ casein hydrolysate medium; and single colonies were isolated which were then dried by the Stamp (1947) technique and kept at room temperature.

Growth of mutants in liquid cultures. The following minimal medium was used: $\left(\mathrm{NH}_{4}\right)_{2} \mathrm{SO}_{4}, \mathrm{I}$ g.; $\mathrm{NH}_{4} \mathrm{Cl}$, I g.; $\mathrm{KH}_{2} \mathrm{PO}_{4}, \mathrm{I}_{3} \cdot 6 \mathrm{~g}$. This solution was adjusted to $\mathrm{pH} 7.0$ with $\mathrm{I} \cdot \mathrm{O} \mathrm{N}-\mathrm{NaOH}$ and to $\mathrm{I} l$. in volume with distilled water. After sterilization, enough $\mathrm{MgSO}_{4}$ solution was added to make the final concentration $3 \mathrm{~mm}$, and glucose solution to give a final concentration of $0.5 \%$. All incubation in liquid cultures was, with shaking, at $35^{\circ}$.

\section{Table $\mathrm{I}$. Effect of inoculum size on lag and growth rate of mutant rod-4 and the parent Bacillus subtilis 168 trp}

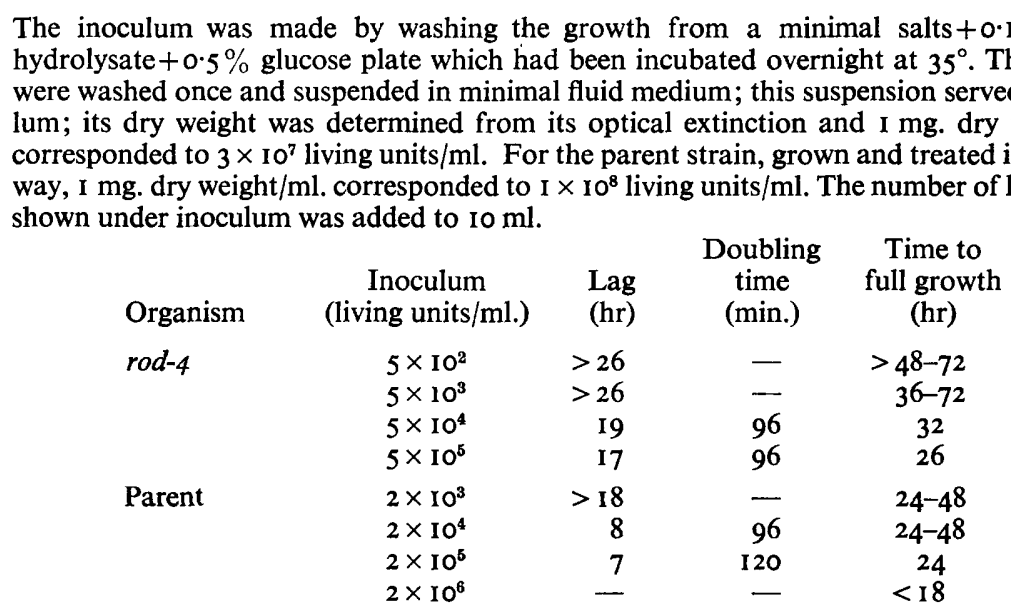

The original agar media used for isolating mutants from Bacillus subtilis $168 \mathrm{trp}$ contained $0.1 \%$ acid hydrolysed casein. With this present the mutants formed larger colonies when growing in the presence of $0.8 \mathrm{M}-\mathrm{NaCl}$ than when growing without the high salt concentration. They would, however, grow on the minimal agar medium in the absence of the sodium chloride and the casein hydrolysate. They would also grow in the liquid minimal medium described in Methods; the lag in growth in this latter 
medium was inoculum-dependent. Results were concerned with the growth of the parent strain and mutants in the liquid minimal medium (Table I). The lag in growth of the parent was also dependent on inoculum size; the principal difference between the mutant and the parent was in the length of the lag period. Attempts to overcome the lag in the growth of the mutant by the addition of heat-killed bacteria were unsuccessful; but it could be achieved by the addition of low concentrations of casein hydrolysate.

\section{Preparation of cell walls}

For lysozyme treatment. Cultures of one of the mutants and of wild-type Bacillus subtilis $168 \mathrm{trp}$ were grown on salts + casein hydrolysate agar medium with and without the addition of $0.8 \mathrm{M}-\mathrm{NaCl}$. After 2 days of incubation at $35^{\circ}$, the bacteria were harvested in a solution of $2 \%(\mathrm{w} / \mathrm{v})$ sodium dodecyl sulphate. They were then broken by shaking with Ballotini beads for about 20 min. in a Mickle (1948) disintegrator working at 0 to $4^{\circ}$. The resulting cell walls were washed with sodium dodecyl sulphate at room temperature until they were protein-free, then with M-sodium chloride and finally with water until they were free from chloride. The walls were then lyophilized.

For autolysis. Cultures of two of the mutants of Bacillus subtilis 168 trp were grown in liquid minimal medium containing casein hydrolysate with and without $0.8 \mathrm{M}-\mathrm{NaCl}$. The bacteria were harvested towards the end of the exponential phase of growth, broken by shaking with Ballotini beads in a Braun cell homogenizer and then washed six times with water and lyophilized. The temperature was at about $2^{\circ}$ throughout the treatment.

\section{Electron microscopy}

Colonies of bacteria were removed from the surface of agar plates with a platinum loop and placed in the fixative. In some cases the samples were fixed with $5 \%$ glutaraldehyde in $0.05 \mathrm{M}$-cacodylate buffer ( $\mathrm{pH} \mathrm{7.2)}$ containing $10 \mathrm{~mm}-\mathrm{CaCl}_{2}$ for $2 \mathrm{hr}$. Following overnight wash in cold buffer, the samples were fixed with $\mathrm{I} \% \mathrm{OsO}_{4}$ by the method of Ryter \& Kellenberger (1958); some samples were placed directly in the $\mathrm{OsO}_{4}$ fixative without prefixation with glutaraldehyde. Similar results were obtained with these two fixation procedures. Before dehydration in ethanol the pellets of fixed bacteria were soaked for a minimum period of $2 \mathrm{hr}$ in $0.5 \%$ uranyl acetate dissolved in the Ryter-Kellenberger buffer. All samples were embedded in Epikote 8I 2 resin. Sections were cut with glass knives on an LKB Ultrotome and picked-up on bare 400-mesh copper grids. The sections were stained with uranyl acetate (a saturated solution in $50 \%, w / v$, ethanol in water), or with uranyl acetate and lead citrate (Venable \& Coggeshall, 1965). Some sections were lightly coated with carbon before examination in the electron microscope. Serial sections were picked up on slot Sjöstrand-type grids covered with a Formvar film, stained with uranyl acetate and then stabilized with carbon. Sections were examined in either a Philips EM-300 or a Philips EM-200 operated at $60 \mathrm{kV}$ and $80 \mathrm{kV}$, respectively, with $50 \mu \mathrm{m}$. objective apertures and doublecondenser illumination. In both microscopes the specimen chamber was surrounded by a liquid-nitrogen anticontamination trap.

\section{Spore formation}

Cultures of three of the mutants grown overnight in salts casein hydrolysate $(0 \cdot \mathrm{I} \%)$ liquid medium were used to inoculate media of the following composition: Evans Peptone, Io g.; Lemco, 3 g.; sodium chloride, 2 g., made to I 1. in ion-exchange water 
and adjusted to $\mathrm{pH} 7 \cdot \mathrm{I}$ before autoclaving. Samples were withdrawn every $48 \mathrm{hr}$ and appropriate dilutions heated at $75^{\circ}$ for $15 \mathrm{~min}$. The heated and unheated cultures were then plated on Hedley-Wright nutrient agar. The plates were incubated for $24 \mathrm{hr}$ at $35^{\circ}$ and the number of colonies developing from the heated cultures was taken as indication of the number of spores in the original broth cultures.

\section{RESULTS}

\section{Mutants isolated}

Most of the work reported here is concerned with mutants isolated from Bacillus subtilis $\mathrm{I} 68 \mathrm{trp}$. In this strain mutants were recognized at the rate of about $\mathrm{I}: 4000$ of those micro-organisms surviving the mutagen treatment. Thirty isolates were made which had the appearance under phase contrast (PI. I, fig. 2) when they were grown on minimal salts + glucose agar with no added sodium chloride. All of these isolates required tryptophan for growth and all showed some tendency to revert to the parent phenotype, which could be readily recognized on the plates by larger rough colonies. Of the 30 isolates, $\mathrm{I} 3$ were kept for further study. When these 13 were grown on the medium containing $0.8 \mathrm{M}-\mathrm{NaCl}$, nine of them changed to rod-like forms (Pl. I, fig. 3) but four did not change. Those that will change will be referred to as class A rod mutants; those that do not will be called class B. From Bacillus licheniformis 9945A met cap, six class A mutants were isolated. Three of these had the appearance shown in Pl. I, fig. I, and were very like those obtained from B. subtilis; three were less coccoid but of a similar type. All required methionine for growth and did not form polyglutamic acid. When grown in media containing $0.8 \mathrm{M}$-sodium chloride they also formed rod-like bodies. About 30 mutants were obtained from $B$. licheniformis 6346; all grew as rodlike forms in the presence of $0.8 \mathrm{M}-\mathrm{NaCl}$. Some mutants of the rod type were also isolated from B. licheniformis 6346 lys and lys str-r, but the auxotrophic markers could not always be shown in the rod mutants; these will be disregarded in this paper, though morphologically they appeared identical to other rod mutants.

\section{General physiological characteristics of the mutants from Bacillus subtilis}

Fermentation characteristics. Apart from the slight fermentation of sorbitol by Bacillus subtilis rod-4 and of maltose by the parent strain, the results (Table 2) for the parent and the two mutants were identical. In some instances fermentation by the mutants appeared to be slightly slower than for the parent; this is to be expected from their overall slower growth.

Sensitivity to antibiotics. The results obtained are shown in Table 3. The Bacillus subtilis mutants (rod-4, rod-5) showed qualitatively the same pattern of sensitivity to the four antibiotics tested. Both mutants are sensitive to all four antibiotics (Table 3) and rod-4 quantitatively has the same pattern as the parent. Surprisingly, rod-5 is considerably more sensitive to all the antibiotics except chloramphenicol.

Effects of lysozyme and autolysin. Both Bacillus subtilis and B. licheniformis have walls that are sensitive to egg-white lysozyme and the bacteria are in consequence lysed by this enzyme. The effect of lysozyme on the mutants was studied by growing them on the usual solid medium with and without $0.8 \mathrm{M}-\mathrm{NaCl}$ and then suspending the bacteria in $0.1 \mathrm{M}$-ammonium acetate buffer at $\mathrm{pH} 6.5$. Egg-white lysozyme solution was added to half of each suspension to a final concentration of $50 \mu \mathrm{g}$. $/ \mathrm{ml}$., whilst an 
equivalent volume of water was added to the other half. Drops of cultures were examined under the phase-contrast microscope. The mutants were more sensitive than the parent strain and there was no obvious difference according to whether the mutants

\section{Table 2. The fermentation tests on the parent and rod mutants of Bacillus subtilis 168 trp}

Incubation was station. culture at $35^{\circ}$ in test-tubes containing inverted Durham tubes. The symbols + to +++ indicate increasing degrees of acidity. 0 means no acid and Alk means that alkalinity was produced. The inoculum was a suspension of the organisms obtained by emulsifying a few colonies from plates of the $0.1 \%$ casein hydrolysate salts glucose agar in liquid minimal medium. The basal medium for the sugar solutions was peptone water.

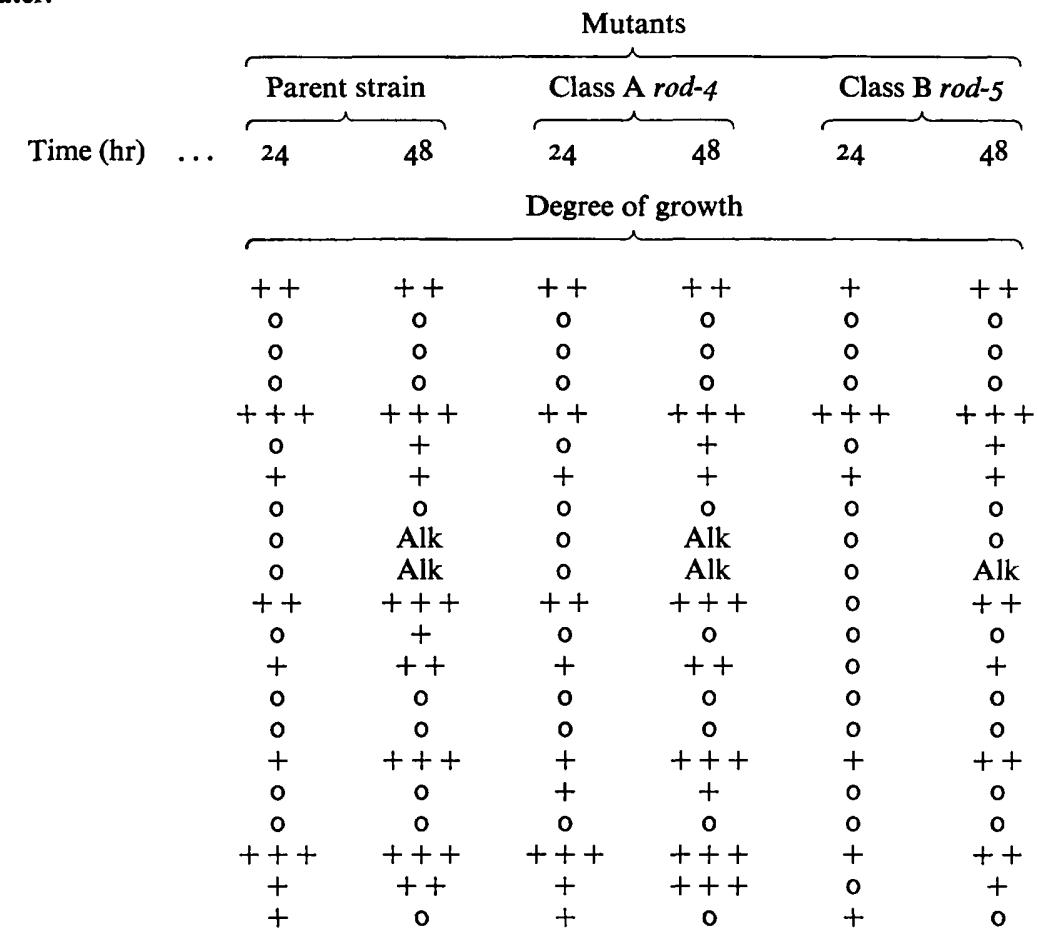

Carbohydrate

Arabinose

Dextrin

Dulcitol

Galactose

Glucose

Glycerol

Glycogen

Inositol

Inulin

Lactose

Fructose

Maltose

Mannitol

Raffinose

Rhamnose

Salicin

Sorbitol

Starch

Sucrose

Trehalose

Xylose

Table 3. The antibiotic sensitivity of rod mutants of Bacillus subtilis compared with the parent

The growth medium was the salts + casein hydrolysate agar medium described in Methods. All inocula were first grown for $24 \mathrm{hr}$ on the same medium. For testing the effect of benzylpenicillin the $24 \mathrm{hr}$ cultures were subsequently grown in Penassay broth to about the middle of the exponential phase of growth and then diluted before plating to give about 300 colonies/ plate. The figures recorded are those for the highest concentration $(\mu \mathrm{g} . / \mathrm{ml}$.) showing growth and the lowest showing no growth after 4 days at $35^{\circ}$.

\begin{tabular}{|c|c|c|c|}
\hline Antibiotic & $\begin{array}{l}\text { Parent } \\
(\mu \mathrm{g} . / \mathrm{ml} .)\end{array}$ & $\begin{array}{c}\text { rod-4 } \\
(\mu \mathrm{g} . / \mathrm{ml} .)\end{array}$ & $\begin{array}{c}\text { rod }-5 \\
(\mu \mathrm{g} . / \mathrm{ml} .)\end{array}$ \\
\hline Benzylpenicillin & 0.01 to 0.05 & 0.01 to 0.05 & 0.005 to 0.01 \\
\hline Tetracycline & 10 to 50 & IO to 50 & I to IO \\
\hline Erythromycin & I to 10 & I to Io & 0 to 0.1 \\
\hline Chloramphenicol & I to 10 & I to IO & I to IO \\
\hline
\end{tabular}


were grown in the presence or absence of $\mathrm{NaCl}$. Cell walls of rod-4 were similarly treated by suspending them to I mg./ml. in $0.1 \mathrm{M}$-ammonium acetate buffer ( $\mathrm{pH} \mathrm{6.5)}$ containing $50 \mu \mathrm{g} . / \mathrm{ml}$. lysozyme. The optical density of the suspension was measured at intervals during about $2 \mathrm{hr}$. The rates of lysis of the wall of the wild type and of the mutant grown under the same conditions were very similar. Walls from bacteria grown on salts + casein hydrolysate medium containing $0.8 \mathrm{M}-\mathrm{NaCl}$ (Fig. I) lysed more slowly. When suspensions of the mutants or of wall preparations from them

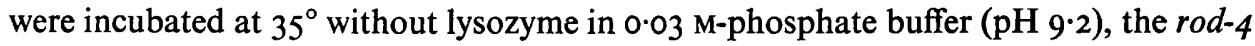
and rod-5 mutants lysed, providing they had been grown without $\mathrm{NaCl}$. Free amino groups of $\mathrm{L}$-alanine appeared, showing that an autolysin of the type previously studied (Young, 1966) in the parent strain was active in the mutants.

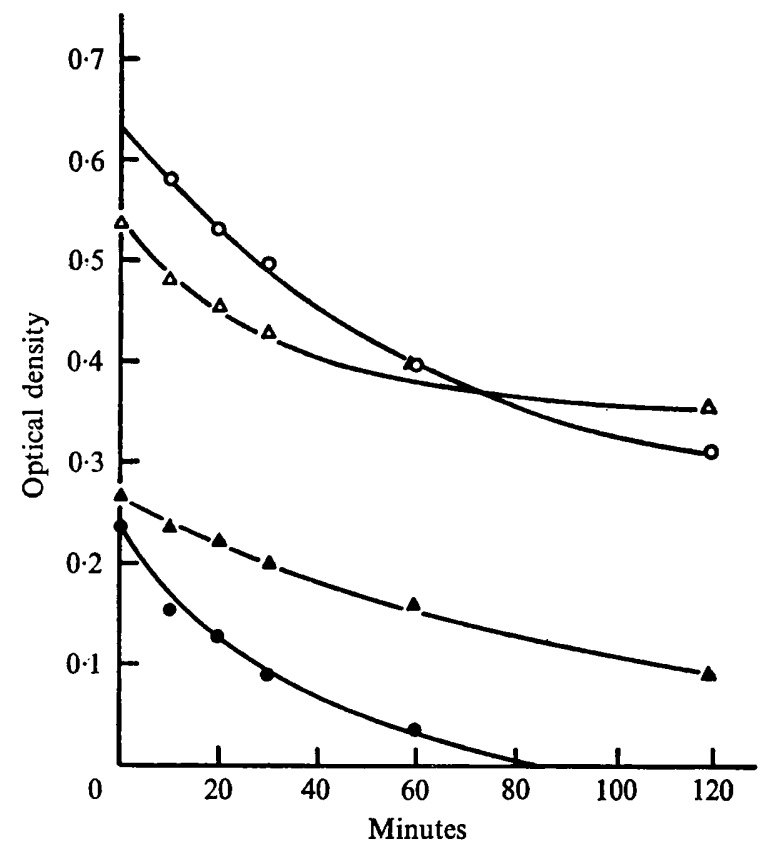

Fig. I. Rate of lysis of cell walls of Bacillus subtilis I $68 \mathrm{trp}$ and of the mutant rod-4. The cell walls were suspended in $0.1 \mathrm{M}$-ammonium acetate buffer $(\mathrm{pH} \mathrm{6.5)}$ to approx. $1 \mathrm{mg} . / \mathrm{ml}$. Lysozyme was added to $50 \mu \mathrm{g} . / \mathrm{ml}$. At intervals the extinction of the culture was read. $\mathrm{O}$, Wall from rod-4; 0 , wall from wild type, both grown on salts + casein hydrolysate medium; $\triangle$, wall from rod-4; $\Delta$, wall from wild type 168 , both grown in salts + casein hydrolysate medium containng $0.8 \mathrm{M}-\mathrm{NaCl}$.

The effect of temperature on growth. Plates of the usual salts + casein hydrolysate medium, with and without $0.8 \mathrm{M}-\mathrm{NaCl}$, were inoculated from plates of the same media with rod-4, rod-5 and the parent strain. The plates were incubated at $45^{\circ}, 35^{\circ}, 25^{\circ}$, room temperature (about $18^{\circ}$ ) and $4^{\circ}$. Growth was recorded after 3 days of incubation. Table 4 shows that the mutants differed from the parent in not growing at $45^{\circ}$ in absence of $\mathrm{NaCl}$. When $0.8 \mathrm{M}-\mathrm{NaCl}$ was present, a little growth occurred at $45^{\circ}$ with rod-4 and rod-5. There appeared to be some evidence that at the lower growth temperatures rod-4 formed longer rods in the presence of $\mathrm{NaCl}$ than at the higher temperatures. An occasional rod was also seen in the mutant rod-5 growing at room temperature in 
the presence of $0.8 \mathrm{M}-\mathrm{NaCl}$. During this work it was observed that the mutants were more susceptible than the parent strain to cold shock and that rod-4 was more susceptible than rod-5. For example, live organisms of rod-5 and the parent could be recovered from a plate streaked and stored at $0^{\circ}$ up to 6 days; at io days there was no recovery from rod-5. No recovery was made from rod- 4 after 4 days without $0.8 \mathrm{M}-\mathrm{NaCl}$, and after 5 days no recovery was made from this plate. The plates were removed from the refrigerator to room temperature each day for examination and subculture.

The effect of direct changes in osmolarity on the morphological form. Transfer of

\section{Table 4. The effect of the temperature upon rod mutants and the parent strain}

The agar medium was the salts medium $+0.1 \%$ casein hydrolysate described in Methods with and without the addition of $0.8 \mathrm{M}-\mathrm{NaCl}$. The degree of growth is the growth recorded as from $o$ to +++ . The terms rod and round refer to the appearance of the growth under the phase-contrast microscope.

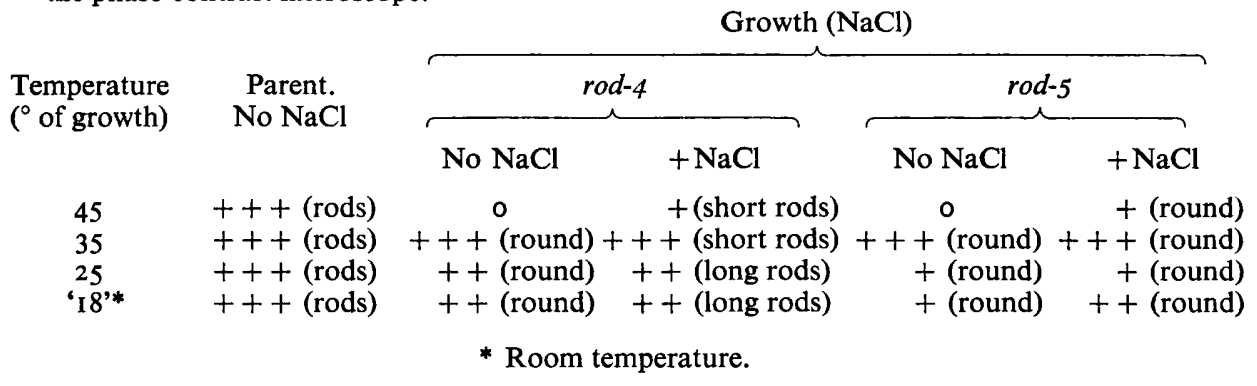

Table 5. The effect of increasing concentrations of sodium and potassium chloride upon morphology of the rod mutants of Bacillus subtilis 168 trp

The basal medium was the $0.1 \%$ casein hydrolysate + salts + agar medium described in Methods. Incubation was for $18 \mathrm{hr}$ at $35^{\circ}$. The morphology was observed with the phasecontrast microscope. The words italicized indicate the concentrations at which morphological change was clear.

\begin{tabular}{|c|c|c|c|c|c|c|}
\hline \multirow{3}{*}{$\begin{array}{l}\text { Conc. } \\
\text { (M) }\end{array}$} & \multirow[b]{3}{*}{ Salt } & \multicolumn{5}{|c|}{ Mutants } \\
\hline & & \multicolumn{3}{|c|}{ Class A } & \multicolumn{2}{|c|}{ Class B } \\
\hline & & rod -3 & $\operatorname{rod}-4$ & $\operatorname{rod}-7 c$ & rod-7d & rod-8 \\
\hline 0 & $\mathrm{NaCl}$ & Round & Round & Round & Round & Round \\
\hline 0.1 & & Round & Round & Round & Round & Round \\
\hline 0.2 & & Round & Short rods & $\begin{array}{l}\text { Round+ } \\
\text { short rods }\end{array}$ & Round* & Round \\
\hline 0.4 & & Short rods & Short rods & Short rods & Round & Round* \\
\hline 0.6 & & Short rods & Short rods & Rods & Round & Round \\
\hline 0.8 & & Short rods & Long rods & Thin rods & Round* & Round* \\
\hline $1 \cdot 0$ & & Long thin rods & Long thin rods & Rods & Round* & Round* \\
\hline$I \cdot 2$ & & Long thin rods & Long thin rods & Long rods & Round & Round \\
\hline 0.1 & $\mathrm{KCl}$ & Round & Round & Round & Round & Round \\
\hline 0.2 & & Round & Round & Round & Round & Round \\
\hline 0.4 & & Short rods & Round & Short rods & Round & Round \\
\hline 0.6 & & Short rods & Short rods & Short rods & Round $\dagger$ & Round $\dagger$ \\
\hline 0.8 & & Short rods & Short rods & Long rods & Round $\dagger$ & Round $\dagger$ \\
\hline
\end{tabular}


bacteria of rod-4 grown as rods on a medium containing $0.8 \mathrm{M}-\mathrm{NaCl}$ to distilled water did not alter the morphology of the bacteria, and vice versa.

The effect of increasing concentration of salts in the growth medium. Table 5 shows the effect of increasing concentrations of sodium and potassium chloride added to $0.1 \%$ casein hydrolysate-salts + agar medium. There appeared to be little difference between sodium and potassium chlorides. In the presence of both chlorides the class $\mathrm{A}$ mutants grew as rods at about $0.4 \mathrm{M}$. For rod-4 the sodium salt appeared to be more effective, since the mutant appeared as rods at $0.2 \mathrm{M}$ whereas $0.6 \mathrm{M}$, potassium salt was required. The class $B$ mutants did not grow as rods in any of the media; an occasional rod-like form was seen with higher concentrations of both salts.

Spore formation. Two class-A and one class-B mutants were tested for spore formation. After $4^{8} \mathrm{hr}$ the cultures of the two A mutants consisted of about $50 \%$ spores. There were no spores in the rod-5 culture.

Viable counts. Attempts to see whether each individual round form was alive and capable of giving rise to a rod have so far been complicated by the occurrence of large groups or strings of round forms and by the formation of filaments during the transition from the round form to the rods (Rogers \& McConnell, 1970). A relationship was established between the turbidity and the dry-weight content of suspensions of the mutant rod-4 grown as a round form. Suspensions were then washed from $0.1 \%$ casein hydrolysate-agar plates and living counts measured both on the same medium and on nutrient agar. The mutant grew on the former medium as a round form and on the latter as a rod. The same was done for the parent $B$. subtilis $168 \mathrm{trp}$. The viable counts for the parent strain growing on either medium were $9.5 \times 10^{7}$ to $1.05 \times 10^{8}$ colonyforming units/mg. dry weight. The counts for the mutant were again the same within $5 \%$ on the two media but only $3.3 \times 10^{7}$ colony-forming units $/ \mathrm{mg}$. dry weight were present. Measurements of the number of colony-forming units in a liquid minimal medium culture of rod-4 incubated for $48 \mathrm{hr}$ into the late exponential or early stationary phase gave $1 \cdot 9 \times 10^{6}$ colony-forming units $/ \mathrm{mg}$. dry weight. The discrepancies between the colony-forming units/unit mass bacteria may be due to different sizes of clumps or to the presence of a different proportion of living bacteria. The correspondence between the number of colonies appearing on poor and rich medium, respectively, suggests that any unit capable of forming a colony of round forms can also form a colony of rods (see later, this paper). The proportion of individual round forms that is viable either as round forms or as rods cannot so far be deduced.

\section{Detailed electron microscopic observations on rod-4 derived from Bacillus subtilis}

Appearance when grown in absence of added $\mathrm{NaCl}$. The picture at low magnification (Pl. 2, fig. 4) illustrates the bizarre shapes, the variable thickness of the cell wall, the erratic beginnings of division septa and the apparently dispersed nuclear body. This picture may be compared with those of the parent Bacillus subtilis already published (e.g. van Iterson, I96I; Ryter \& Landman, 1964). The cell walls may be fairly thin (approx. I35 $\AA$ in width) or very much thickened (up to I $800 \AA$ ). When thick, they appear to be multilayered (Pl. 3, fig. 6; P1. 5, fig. I2, I3; Pl. 7, fig. 22), each layer being 50 to $85 \AA$ wide. In most organisms the inner edge of the cell wall is composed of a densely staining zone (Pl. 4 , fig. 8 ) which is 55 to $65 \AA$ thick. This zone is usually absent from the outer surface of the wall but is present on both edges of septa. Occasionally there appear to be two distinct walls surrounding some cells (P1. 4, fig. 7). The inner 
wall member, presumably that most recently formed, bears a densely staining zone on both the inner and outer faces (Pl. 4, fig. 9). Irregular thickenings may occur in these walls (Pl. 4, fig. Io) and appear multilayered.

The surface layers of the cell wall usually appear frayed (e.g. Pl. 3, fig. 6). This fraying could be a preparative artifact, but preliminary examination of negatively stained organisms shows a system of fine fibrils and amorphous material to be associated with the walls. In section, the frayed-wall material is present as strands lying side by side, suggesting a breakdown of the multilayered structure (Pl. 5, fig. I3). Septa sometimes have a moth-eaten appearance (Pl. 5, fig. I I) where a lytic enzyme may have been active. Fine strands of material appear to extend across the septum in these areas. Serial sections show that these patches are apparently continuous throughout the septum and are not confined to discrete areas. They also show that the septa are arranged in an irregular manner (Pl. 6, fig. I4 to $2 \mathrm{I}$ ).

The cytoplasmic membrane is approximately 90 to $120 \AA$ thick and bears a fringe of dense material up to $65 \AA$ thick on its outer surface, and thus appears to be asymmetric (Pl. 4, fig. 8). The material on its outer edge is of similar density to the inner edge of the cell wall. The membrane may be slightly infolded at irregular intervals along its length (Pl. 4, fig. 8) or drawn into small vesicles facing the wall (PI. 5, fig. I2). Mesosomes like those of the normal type were never seen, but sheets of membrane and vesicles were present, usually in association with the wall or with the septa (Pl. 7, fig. 22 to 24). Some of these vesicles appear to contain electron-dense material (Pl. 7, fig. 22, 24).

The nuclear body appears to be dispersed throughout the cytoplasm as fine fibrils in discrete areas of low electron-density (Pl. 7, fig. 25). There is some suggestion that the fibrils of the nuclear body may be dispersed in the form of a reticulum linking the apparently isolated areas of cytoplasm. No connexion of the nuclear body to a membranous structure has been observed.

Appearance when grown in media containing increasing concentrations of sodium chloride. Growth of the mutant in these media produces a number of striking changes. The most obvious of these is an alteration of shape from predominantly round to rod-shaped organisms. At the ultrastructural level, conspicuous changes concern the condensation of the nuclear body, the restoration of orderly division septa and a decrease in the thickness of the cell wall. Membranous structures in the cytoplasm also become more evident. In $0 \cdot \mathrm{I} \mathrm{M}-\mathrm{NaCl}$ the organisms are still round in shape. The cell wall is thinner but still appears layered. The outer surface of the wall is relatively smooth in outline and less frayed (Pl. 8, fig. 26, 29); the inner edge is again composed of a densely staining zone. The septa are considerably thickened, however, and rarely appear in apposition. Associated with the septa are a number of vesiculate bodies resembling mesosomes (Pl. 8, fig. 27). These structures are occasionally lamellar (Pl. 8, fig. 28) and appear to be free in the cytoplasm or possibly associated with the nuclear body. The latter is composed of bundles of fibrils aligned in parallel array, and thus appears condensed into long strands which are often lobed in appearance (Pl. 8, fig. 26). Different bacteria from the same sample show varying degrees of condensation of the nuclear body. Surrounding the nuclear body and scattered throughout the cytoplasm are areas of material most of which were amorphous though some appeared crystalline.

In $0.2 \mathrm{M}-\mathrm{NaCl}$ many of the bacteria were round but a few were rod-shaped. The wall was smooth in outline and evidence of layering was less apparent (Pl. 9, fig. 30). Between dividing bacteria the septum appeared to be chewed away, more particularly 
at the middle and ends (Pl. 9, fig. 30). Few mesosome-like structures were seen in these bacteria. The nuclear body occupied a median position and was highly condensed. Unlike the bacteria grown in $0^{\cdot} \mathrm{I} \mathrm{M}-\mathrm{NaCl}$, the nuclear body was more usually oval not lobed in outline. The fibrils were whorled in appearance and seemed clumped at certain positions, which may represent transverse sections of the fibrils. Amorphous material was again present throughout the cytoplasm.

The bacteria in $0.4 \mathrm{M}-\mathrm{NaCl}$ closely resembled those grown in media supplemented with $0.2 \mathrm{M}-\mathrm{NaCl}$. In many bacteria, the nuclear body was surrounded by a distinct ring of cytoplasmic material containing ribosomes (Pl. 9, fig. 3I) or fibrillar material (P1. 9, fig. 32). In some sections plugs of cytoplasmic material appeared in the middle of the nuclear body, and the latter appeared to be woven around them (Pl. 9, fig. 3I). The fibrils of the nuclear body were again aggregated at a number of points (Pl. 9, fig. 3I). Peripheral to the cytoplasm, and within the plugs, were zones of amorphous material, and lamellar membranous structures were occasionally present in the cytoplasm.

Bacteria grown in $0.8 \mathrm{M}-\mathrm{NaCl}$ presented a complex array of variation in shape, cell wall structure and position of the nuclear body. Examination of a large number of sections suggested that these variants could be classified into three types. The most usual variant was rod-shaped, with orderly division septa and a highly condensed nuclear body (Pl. Io, fig. 33 to 34 ). The cell wall was approximately $270 \AA$ wide and was much thickened at the septa and at the poles of the cell. At these positions the wall appeared to be layered and fibrous in texture (Pl. I I, fig. 44); the wall was frayed at some points along its length. Invaginations of the cytoplasmic membrane were associated with the walls and septa, but did not resemble normal mesosomes. Material of similar electron-density to the wall was present within these infoldings (Pl. I I, fig. 42 ; Pl. I2, fig. 48). Protrusions of the membrane near the septa were sometimes present (PI. I I, fig. 42). The nuclear body was median in position and highly condensed, the fibrils appearing coarsely aggregated into bundles (Pl. I0, fig. 36). In some cells the DNA was less aggregated, but patches of amorphous material were lying scattered in the nuclear region. When present in the cytoplasm the amorphous material was in discrete crystalline regions with a repeat period of $56.7 \AA$ (P1. I I, fig. 43). The ribosomes were scattered throughout the cytoplasm. Certain bizarre organisms, highly irregular in shape but possessing the above characteristics, were sometimes present ( $\mathrm{Pl}$. 10, fig. 35).

The second type of variant was a rod-shaped organism bounded by a wall of very variable thickness and rarely possessing division septa (Pl. 10, fig. 37, 38). In this variant the nuclear body was not as condensed as in the above organisms but appeared to be closely associated with, or possibly linked to, the cytoplasmic membrane (PI. IO, fig. $37,38)$. The membrane was infolded and the pockets contained electron-dense material. The cytoplasm was restricted to a ring around the nuclear body by patches of amorphous material (Pl. I I, fig. 40). The third category included spherical bodies resembling protoplasts and spheroplasts. The latter type were continuously bounded by a thin layer of wall, or the wall was present only as short strips. In those resembling protoplasts the outer edge of the cytoplasmic membrane bore a fringe of dense material 35 to $70 \AA$ wide (Pl. Io, fig. 36, 39). Many of these forms appeared to be lysing. The nuclear body was closely associated with the surface membrane (P1. 10, fig. 36). Occasionally scattered patches of amorphous material were present in the cytoplasm.

Associated with bacteria grown in $0.8 \mathrm{M}-\mathrm{NaCl}$ were many vesicular membranous 
bodies, pieces of wall material and strands of nuclear bodies (Pl. ro, fig. 33, 34). Negative-staining of Bacillus subtilis and B. licheniformis confirmed the presence of membranous and amorphous material associated with the organisms. The origin of the vesicles was uncertain. In some organisms vesicles could be seen closely associated with the cell wall in the region of the septum (Pl. I I, fig. 4I). It is not known whether the vesicles actually emerged from the septum, but the wall tended to be frayed at these points.

All the organisms examined from samples grown in $\mathrm{M}-\mathrm{NaCl}$ appeared to be rodshaped, with some tendency to form filaments (PI. I2, fig. 45, 46). The septa and poles of the cells possessed thickened clumps of wall (P1. I2, fig. 49). The nuclear bodies appeared to be more aggregated than those of previously described samples. Associated with the wall were invaginations of the cytoplasmic membrane containing vesicular

Table 6. Bacillus subtilis: the growth of rod mutants on solid media

The abbreviations for the names of media are: $\mathrm{MM}=$ minimal salts medium + glucose + tryptophan $+\mathrm{Mg}^{2+} ; \mathrm{CH}=$ acid hydrolysed casein (Difco) $\mathrm{CH} / \mathrm{S} / \mathrm{C}=\mathrm{I} \%$ casein hydrolysate medium (see Janczura, Perkins \& Rogers, I960); CCY = acid hydrolysed casein, tryptic hydrolysed casein and yeast extract (see Gladstone \& Fildes, 1940); HW=Hedley-Wright nutrient agar (Wright, 1933); YE = minimal medium + yeast extract. The symbols in the Table are: $0=$ round in form; $0=$ fat rod; $-=$ normal rod; $\bar{o}=$ rods and round.

\begin{tabular}{|c|c|c|c|c|c|c|c|}
\hline \multirow{3}{*}{ Mutant no. } & \multirow{3}{*}{ Class } & \multicolumn{6}{|c|}{ Medium } \\
\hline & & MM & $\underset{\text { O. I \% }}{\mathrm{MM}}+$ & $\mathrm{CH} / \mathrm{S} / \mathrm{C}$ & $\mathrm{CCY}$ & HW & YE \\
\hline & & \multicolumn{6}{|c|}{ Morphology } \\
\hline 3 & A & 0 & $\stackrel{\circ}{\circ}$ & 0 & - & - & 0 \\
\hline 4 & $\mathbf{A}$ & 0 & $\circ$ & - & - & - & - \\
\hline $5 \mathrm{a}$ & A? & 0 & 0 & o & 0 & 0 & 0 \\
\hline $5 \mathrm{~b}$ & B & o & 0 & o & $\overline{0}$ & $\bar{o}$ & $\overline{0}$ \\
\hline $7 \mathrm{c}$ & A? & $\circ$ & 0 & 0 & - & - & $\delta$ \\
\hline $7 \mathrm{~d}$ & B & $\circ$ & 0 & 0 & - & o & $\bar{o}$ \\
\hline $8 a$ & B & 0 & 0 & 0 & $\delta$ & 0 & $\bar{\delta}$ \\
\hline
\end{tabular}

structures closely resembling mesosomes (Pl. I2, fig. 47). Tubular and vesicular membranes were sometimes present in the vicinity of the organisms (Pl. I2, fig. 49). Flagella were not detected by negative-staining or sectioning in any samples of organisms grown on solidified minimal medium or on this medium $+\mathrm{NaCl}$. Examination of the mutant grown on the minimal liquid medium $+\mathrm{r} \%(\mathrm{w} / \mathrm{v})$ casein hydrolysate, when it grew as a rod, showed only well-ordered rods with fairly normal mesosomes and with discrete organization of the DNA.

\section{Growth of the mutants from Bacillus subtilis on richer complex media}

Mutants of class A and of class B were streaked on nutrient agar media, HedleyWright agar, C.C.Y. $+\mathrm{I} \%$ glucose agar, minimal salts $+0.5 \%$ glucose medium + yeast extract agar, I \% acid casein hydrolysate $+0.5 \%$ glucose medium $(\mathrm{CH} / \mathrm{S} / \mathrm{C})+$ tryptophan agar. In all cases good growth was obtained after incubation for $\mathrm{I} 8 \mathrm{hr}$ at $35^{\circ}$. All the mutants showed some tendency to change to rod form in some of the rich 
complex media (Table 6). The class-A mutants had less stringent requirements for the change from round form to rod than had class-B mutants. For example, on HedleyWright nutrient agar all the A strains grew completely or partially as rods, whereas two of the B strains remained as cocci and only a few rods appeared in the other. Subcultured on two simpler media, these rods grew as cocci. On media containing yeast extract (i.e. C.C.Y.+Y.E.), however, all the mutants tested showed some rods whilst on $\mathrm{I} \%$ casein hydrolysate medium $(\mathrm{CH} / \mathrm{S} / \mathrm{C})$ only two of the four A mutants were converted.

\section{DISCUSSION}

The gross morphological distortion of these mutants grown without additional salt or organic substances appeared to be associated with disturbed septum formation and membrane arrangement. The DNA also seemed to be more disperse than in any pictures of the parent Bacillus subtilis. This apparently abnormal distribution of the nuclear material was seen whether the bacteria were fixed with glutaraldehyde or treated by the Ryter-Kellenberger (I958) technique; further work is necessary to establish its significance. The condensation of nuclear material by growing the bacteria in higher salt concentrations was reported by Kellenberger (I960) and this phenomenon was very evident in the present work. Serial sections did not show a connexion between the membrane and the DNA in the round form, although such a connexion can readily be demonstrated in the cells of normal Bacillus subtilis and in the mutant grown in high salt concentrations. No mesosomes were found in the round form, although in the rod form shapes which looked like mesosomes were seen. The 'extracellular' membranous bodies in cultures grown in presence of the higher salt concentrations were very reminiscent of the pictures published of staphylococci growing in high salt concentrations (Cripps \& Work, 1967) and may be of similar origin.

It would appear possible that the lesions in the rod mutants were due to blocks in the biosynthesis of the substance or substances in the rich media. Whatever these substances are, they would appear to be necessary for the orderly construction and division of the bacilli. If this is the true explanation, then the effect of salts might be an osmotic remedial effect like those reported for Neurospora crassa (Kuwana, 196I ; Metzenberg, 1968) and Saccharomyces cerevisiae (Hawthorne \& Friis, 1964; Baesel \& Douglas, 1968) in which genetic defects were reversed by low molecular weight substances in the growth medium. The mechanism is not known; the application of this hypothesis will be discussed in the succeeding paper (Rogers \& McConnell, 1970), where it is shown that one of the mutants (rod-4) can be corrected by the presence of glutamate or glutamine in the medium. For this mutant it would appear that the effects of high salt concentration are connected with the availability of this amino acid or its amide, rather than with any effect of the high ionic strength per se.

There is complete similarity between the morphological form of the A mutants reported in the present paper and in Rogers et al. (1968) and those mutants described by Boylan \& Mendelson (1969). Whereas the latter author's organisms rounded up at unfavourable temperatures, ours did so under what were presumably unfavourable nutritional circumstances. It is not without interest that the mutants described here, unlike the parent strain, did not grow at $45^{\circ}$ in the absence of salt, although they did so in its presence. This is the same temperature as that at which the mutant studied by Boylan \& Mendelson (1969) changed to a coccus. Mutants of Escherichia 
coli having a spherical form have also been described (Adler, Terry \& Hardigree, 1968; Hirota et al. 1968; Normark, 1969). So far the physiological basis of these morphological mutants is not clear.

We thank Dr J. Spizizen (Scripps Clinic and Research Foundation, La Jolla, California, U.S.A.) for the gift of the two mutants of B. licheniformis $9945 \mathrm{~A}$ and Dr R. Holliday (this Institute) for many fruitful discussions during this work.

\section{REFERENCES}

Adler, H. I., Terry, C. E. \& Hardigree, A. A. (1968). Giant cells of Escherichia coli. Journal of Bacteriology 95, $\mathrm{r} 39$.

Baesel, J. \& Douglas, H. C. (1968). Osmotic remedial response in a galactose-negative mutant of Saccharomyces cerevisiae. Journal of Bacteriology 95, $\mathrm{I} 103$.

Boylan, R. J. \& MeNDELson, N. H. (1969). Initial characterization of a temperature-sensitive rod mutant of Bacillus subtilis. Journal of Bacteriology 100, 1316.

CRIPPS, R. E. \& WoRK, E. (1967). The accumulation of extracellular macromolecules by Staphylococcus aureus grown in the presence of sodium chloride and glucose. Journal of General Microbiology 49, 127.

Gladstone, G. P. \& Fildes, P. (I940). A simple culture medium for general use without meat extract or peptone. British Journal of Experimental Pathology 21, 161 .

Hawthorne, D. C. \& Fries, J. (1964). Osmotic-remedial mutants. A new classification for nutritional mutants in yeast. Genetics, Princeton. 50, 829.

HiRota, Y., RYTER, A. \& JACOB, F. (1968). Thermosensitive mutants of Escherichia coli affected in the process of DNA synthesis and cellular division. Cold Spring Harbor Symposia on Quantitative Biology 33, 677.

VAN ITERSON, W. (196I). Some features of a remarkable organelle in Bacillus subtilis. Journal of Biophysical and Biochemical Cytology 9, 183.

JACOB, F., RYTER, A. \& CUZIN, F. (1966). On the association between DNA and membrane in bacteria. Proceedings of the Royal Society Ser. B, 164, 267.

JANCZURA, E., Perkins, H. R. \& Rogers, H. J. (1960). Teichuronic acid: a mucopolysaccharide present in wall preparations from vegetative cells of Bacillus subtilis. Biochemical Journal 8o, 82.

KellenBerger, E. (1960). The physical state of the bacterial nucleus. In Microbial Genetics 10, 39. Symposia of the Society for General Microbiology.

Kuwana, H. (196I). Studies on a temperature-sensitive irreparable mutant of Neurospora crassa. II. Osmotic nature of the mutant b 39a. Japanese Journal of Genetics 36, I87.

LANDMAN, O. E. \& HALLE, S. (1963). Enzymically and physically induced inheritance changes in Bacillus subtilis. Journal of Molecular Biology 7, 721.

LANDMAN, O. E., Ryter, A. \& FréHel, C. (1968). Gelatin-induced reversion of protoplasts of Bacillus subtilis to the bacillary form. Electron-microscopic and physical study. Journal of Bacteriology 96, 2154 .

MANGIARotti, G., ApIRIon, D. \& Schlessinger, D. (I966). Selection of sucrose-dependent Escherichia coli to obtain enveloped mutants and fragile cultures. Science, New York 153, 892.

Mendelson, N. H. \& Gross, J. D. (1967). Characterisation of a temperature-sensitive mutant of Bacillus subtilis defective in deoxyribonucleic acid replication. Journal of Bacteriology 94, I603.

MetZenBerg, R. L. (1968). Repair of multiple defects of a regulatory mutant of Neurospora by high osmotic pressure and reversion. Archives of Biochemistry and Biophysics 125, 532.

MickLe, H. (1948). Tissue disintegrator. Journal of the Royal Microscopical Society 68, 10.

NormarK, S. (1969). Mutation in Escherichia coli $\mathrm{K}$ I 2 mediating sphere-like envelopes and changed tolerance to ultraviolet irradiation and some antibiotics. Journal of Bacteriology 98, 1274.

Rogers, H. J. \& Perkins, H. R. (1968). Cell Walls and Membranes. London: E. and F. N. Spon Ltd.

ROGERS, H. J. \& MCCONNELL, M. (1970). The role of L-glutamine in the phenotypic change of a rod mutant derived from Bacillus subtilis I68. Journal of General Microbiology 6r, 173.

Rogers, H. J., McConnell, M. \& BurdetT, I. D. J. (1968). Cell wall or membrane mutants of Bacillus subtilis and Bacillus licheniformis with grossly deformed morphology. Nature, London 219, 285. 
RYTER, A. (1968). Association of the nucleus and the membrane of bacteria: a morphological study. Bacteriological Reviews 32, 39.

Ryter, A. \& Kellenberger, E. (1958). Étude au microscope électronique de plasmas contenant de l'acide désoxyribonucleique. I. Les nucléoides des bactéries en croissance active. Zeitschrift für Naturforschung $\mathbf{1 3}_{3}$ B, 597.

RYTER, A. \& LANDMAN, O. E. (1964). Electron microscope study of the relationship between mesosome loss and the stable L state (or protoplast state) in Bacillus subtilis. Journal of Bacteriology 88, 457.

STAMP, LORD (1947). The preservation of bacteria by drying. Journal of General Microbiology $\mathbf{1}, 251$.

Venable, J. H. \& Coggeshall, R. (1965). A simplified lead citrate stain for use in electron microscopy. Journal of Cell Biology 25, 407.

WRIGHT, H. D. (1933). The importance of adequate reduction of peptone in the preparation of media for the pneumococcus and other organisms. Journal of Pathology and Bacteriology 37, 257.

Young, F. (1966). Autolytic enzyme associated with cell walls of Bacillus subtilis. Journal of Biological Chemistry 24I, 3462.

\section{EXPLANATION OF PLATES}

Plate I

Appearance of rod mutants under the phase-contrast microscope.

Fig. I. Bacillus licheniformis 9945 A met cap grown on minimal salts $+0 \cdot 1 \%$ casein hydrolysate agar. $\times \mathbf{I} 800$.

Fig. 2. Bacillus subtilis 168 trp grown on minimal salts agar. $\times 1400$.

Fig. 3. Bacillus subtilis $\mathrm{I} 68$ trp grown on minimal salts agar $+0.8 \mathrm{M}-\mathrm{NaCl} . \times \mathrm{I} 400$.

\section{Plate 2}

Fig. 4. Low-power electron micrograph of rod mutant grown in absence of added $\mathrm{NaCl}$, showing the irregular shape, wall of variable thickness and erratic septa. The nuclear body is dispersed in areas of low electron-density. $\times 29,754$.

Plate 3

Fig. 5, 6. Mutant grown in absence of added $\mathrm{NaCl}$, showing two organisms of very different relative wall thickness; the wall is layered in fig. 6 . Fig. $5: \times 46,701$; fig. $6: \times 60,496$.

Mutant rod-4 grown without added $\mathrm{NaCl}$.

\section{Plate 4}

Fig. 7. Section of a cell of rod-4 in which there appear to be two layers of wall $(a, b)$ separated by a gap. The arrows point to details enlarged in fig. 9 and Io. $\times 60,496$.

Fig. 8. The inner edge of the cell wall (cw) densely stained, but the outer layer not. The stained edge is of similar density to the fringe of material present on the outer edge of the cytoplasmic membrane $(\mathrm{m})$; $\mathrm{f}$, an infolding of the membrane. $\times 289,345$.

Fig. 9. Portion of the organism shown in fig. 7, showing an inner layer of wall densely stained on inner and outer margins (arrow); the outermost wall stained only on its inner face. $\times 208,375$

Fig. 10. Portion of organism shown in fig. 7, showing irregular thickening on the inner wall; the two faces of this layer are densely stained (black arrows); evidence of layering indicated by white arrows. $\times$ I 54,601 .

Mutant rod-4 grown without added $\mathrm{NaCl}$.

Plate 5

Fig. I I. Section of a septum showing areas of possible lytic enzyme activity (s); within these electrontransparent areas are strands of finely fibrillar material (arrows). The edges of the septum are bounded by densely staining zones. $\times 225,046$.

Fig. 12. Enlargement of organism shown in fig. 6, showing presence of vesicular structures in contact with the outer edge of the cytoplasmic membrane (black arrows). The wall is layered (white arrows). $\times 241,975$.

Fig. 13. Section of a wall apparently frayed into four strips (arrows) of similar width but at different stages of breakdown. $\times$ 192,897. 


\section{Plate 6}

Mutant rod-4 grown in absence of added $\mathrm{NaCl}$.

Fig. I4 to 2I. Part of a sequence of serial sections showing irregular growth of septa (arrows). Note areas of low density within the septa are continuous. $\times 16,302$.

Mutant rod-4 grown without added $\mathrm{NaCl}$.

\section{Plate 7}

Fig. 22. Mesosome-like structure (white arrows), consisting of electron-dense vesicles associated with the cell wall. The wall is layered (black arrows). $\times 184,860$.

Fig. 23. Mesosome-like structure consisting of large vesicles bounded by unit membranes lying near the junction of cell wall and septum. $\times 171,405$.

Fig. 24. Vesicular mesosome-like structure; two of the vesicles (arrows) contain material of similar density to regions of the cell wall. $\times$ I09,305.

Fig. 25. High magnification micrograph showing fibrils of the nuclear body (arrows) linked to cytoplasmic material. $\times 443,190$.

\section{Plate 8}

Mutant rod-4 grown in presence of $0 \cdot \mathrm{I} \mathrm{M-NaCl}$.

Fig. 26. Section of a pair of dividing organisms, both round in shape. Nuclear body of the organism on the left is condensed and lobed (white arrows). A mesosome-like structure is present on the right (black arrows). $\times 40,863$.

Fig. 27. Enlargement of vesicular mesosome-like structure shown in fig. 26. $\times$ I43,952.

Fig. 28. Lamellar mesosome-like structure present in association with the nuclear body. $\times 195,000$.

Fig. 29. Section of a rod-shaped dividing organism. Note apposition of septa and condensed lobes of nuclear body. The wall is relatively smooth in outline but thickened at some points. $\times 54,600$.

\section{Plate 9}

Mutant rod-4 grown in presence of $0.2 \mathrm{M}-\mathrm{NaCl}$ (fig. 30) and $0.4 \mathrm{M}-\mathrm{NaCl}$ (fig. 3I, 32).

Fig. 30. Section of a pair of dividing organisms; septum frayed at the ends and at middle. $\times 52,000$.

Fig. 3I. The nuclear body condensed into a ring around a core of cytoplasmic material containing ribosomes (r). Similar cytoplasmic material (r) present at outer boundary of nucleus. The fibrils of the latter are aggregated at several points (arrows). A membranous structure $(\mathrm{m})$ is present in the cytoplasm. $\times$ 104,000.

Fig. 32. The nuclear body is surrounded by fibrillar material (f) external to which are clumps of amorphous material (a). $\times 72,800$.

\section{Plate 1o}

Mutant rod-4 grown in presence of $0.8 \mathrm{M}-\mathrm{NaCl}$.

Fig. 33 to 34 . Sections of rod-shaped organisms bounded by a wall of irregular thickness and containing condensed nuclear bodies. $\times 36,400 ; \times 14,364$.

Fig. 35. Irregularly shaped cell containing condensed nuclear bodies the fibrils of which are coarsely aggregated; wall much thickened in places. $\times 36,400$.

Fig. 36. Protoplast-like organism, with nuclear body in contact with membrane (arrow). $\times 36,400$. Fig. 37 to 38. Thin-walled organisms without division septa, and nuclear body in contact with membrane (arrows). $\times 47,052 ; \times 36,400$.

Fig. 39. Enlargement of part of fig. 36, showing presence of a dense fringe on the outer face of the cytoplasmic membrane of the protoplast-like cell (a). This fringe is also present on the membrane of the cell bounded by a wall (b). $\times 213,200$.

\section{Plate i I}

Mutant rod-4 grown in presence of $0.8 \mathrm{M}-\mathrm{NaCl}$.

Fig. 40. Section of a nuclear body, fibrils aggregated (arrows). Around the nucleus is a ring of fibrillar cytoplasmic material (f), around which is a zone of amorphous material (a). $\times 169,000$.

Fig. 4I. Section of a septum (s) showing presence of vesicles (v) linked with surface or confined to base of septum. $\times 269,093$. 
Journal of General Microbiology, Vol. 6I, No. 2

Plate I
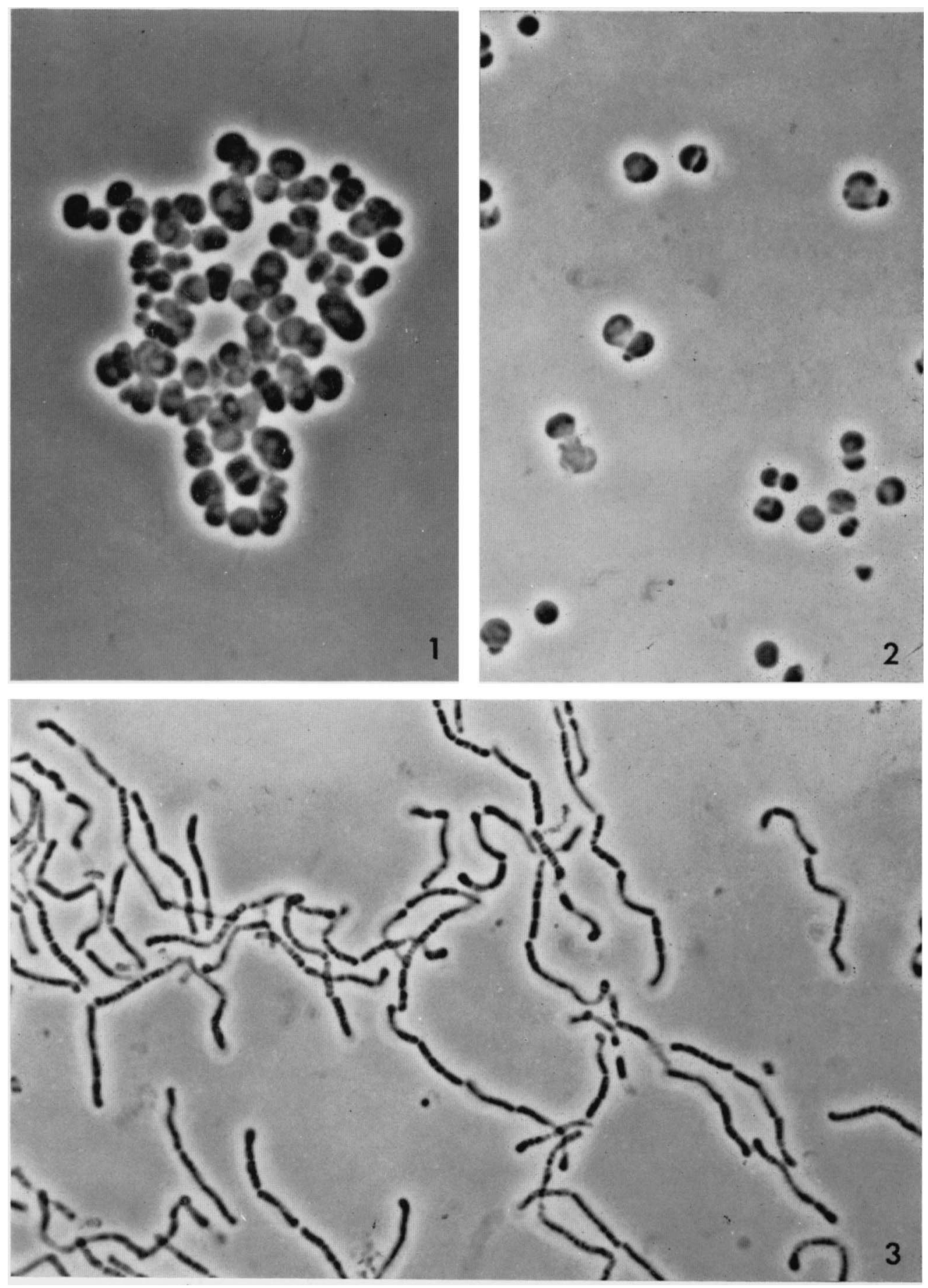

H. J. ROGERS, M. MCCONNELL AND I. D. J. BURDETT

(Facing p. 170) 


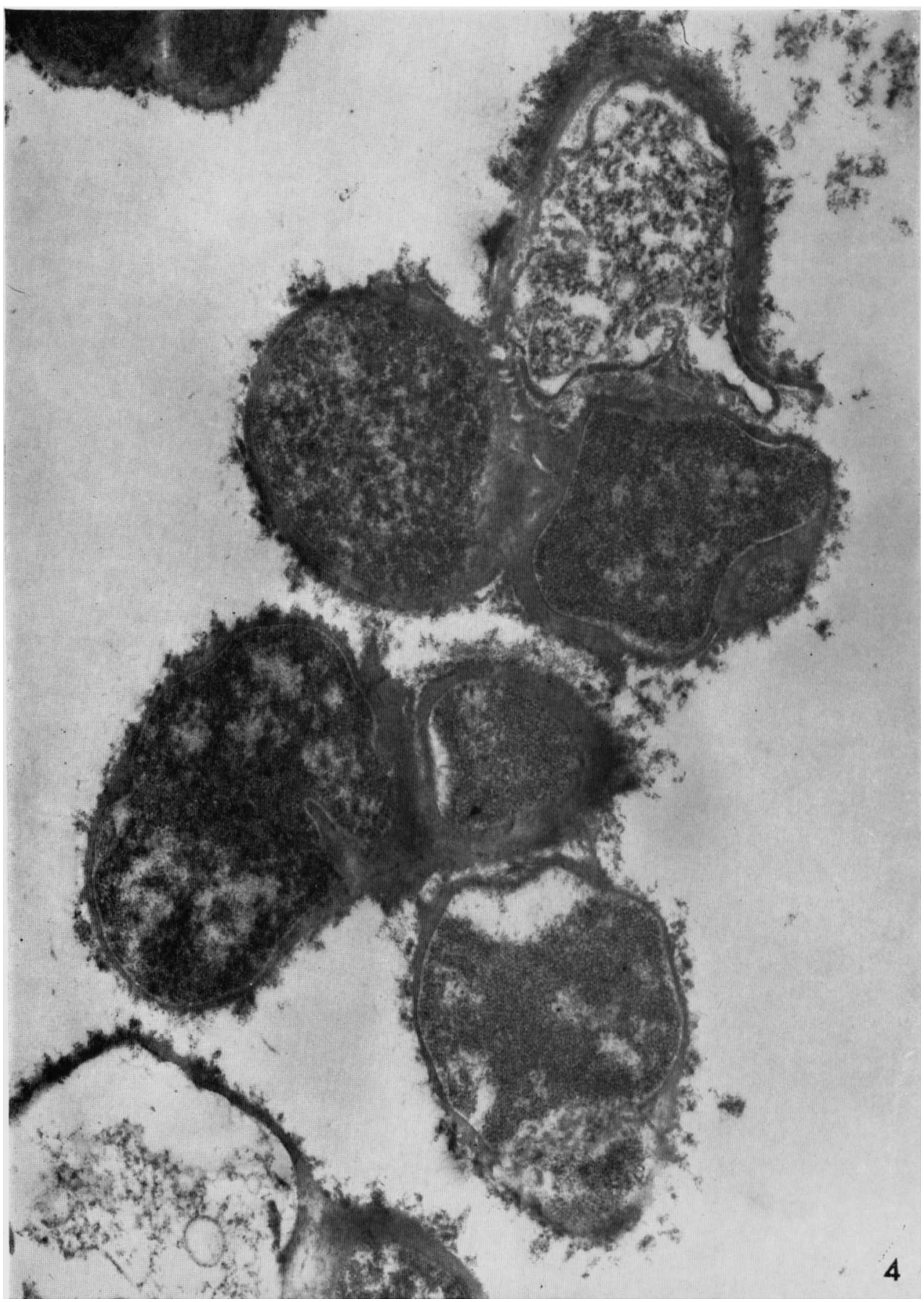

H. J. ROGERS, M. McCONNELL AND I. D. J. BURDETT 
Journal of General Microbiology, Vol. 6r, No. 2

Plate 3
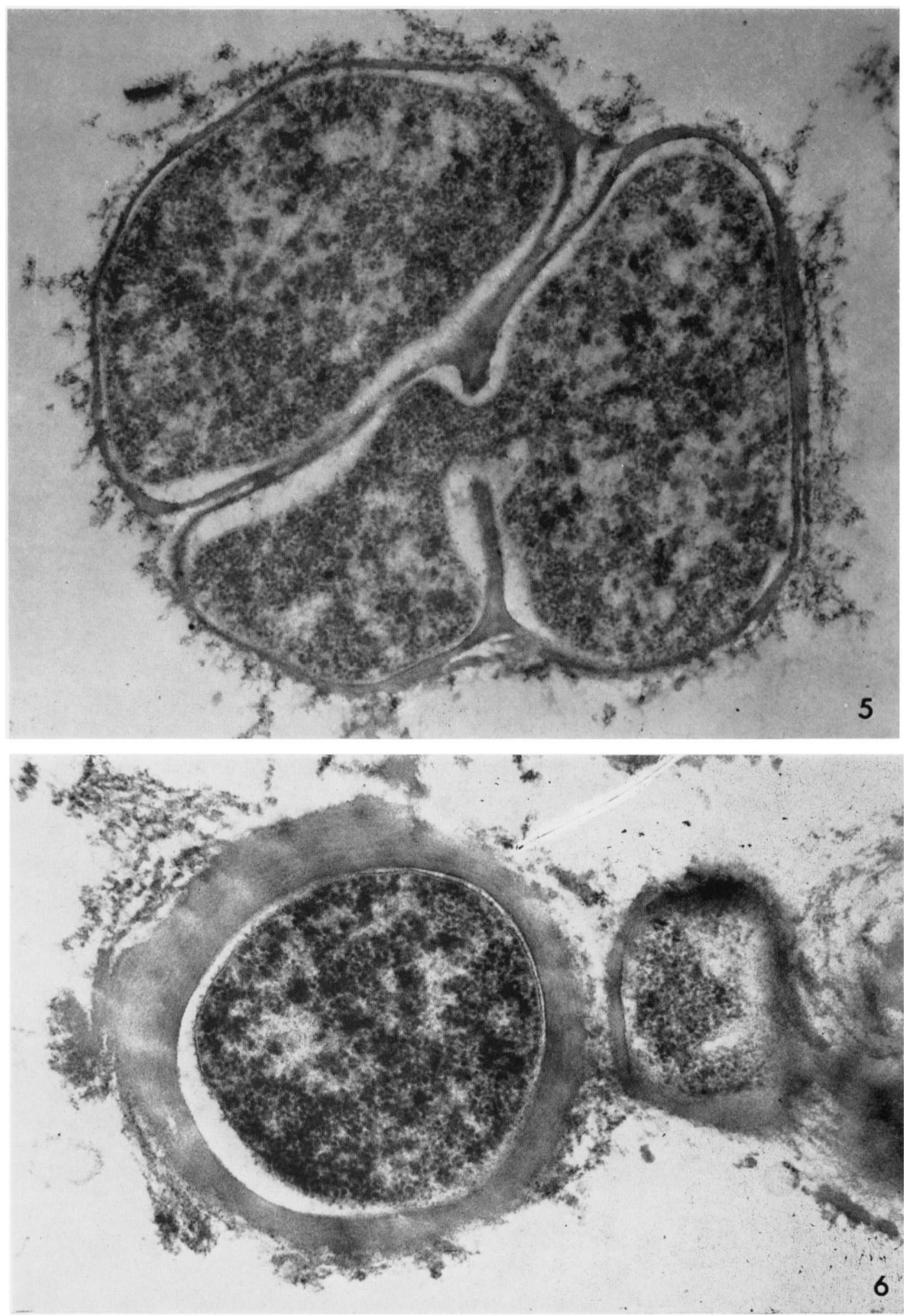

H. J. ROGERS, M. MCCONNELL AND I. D. J. BURDETT 
Journal of General Microbiology, Vol. 6I, No. 2

Plate 4
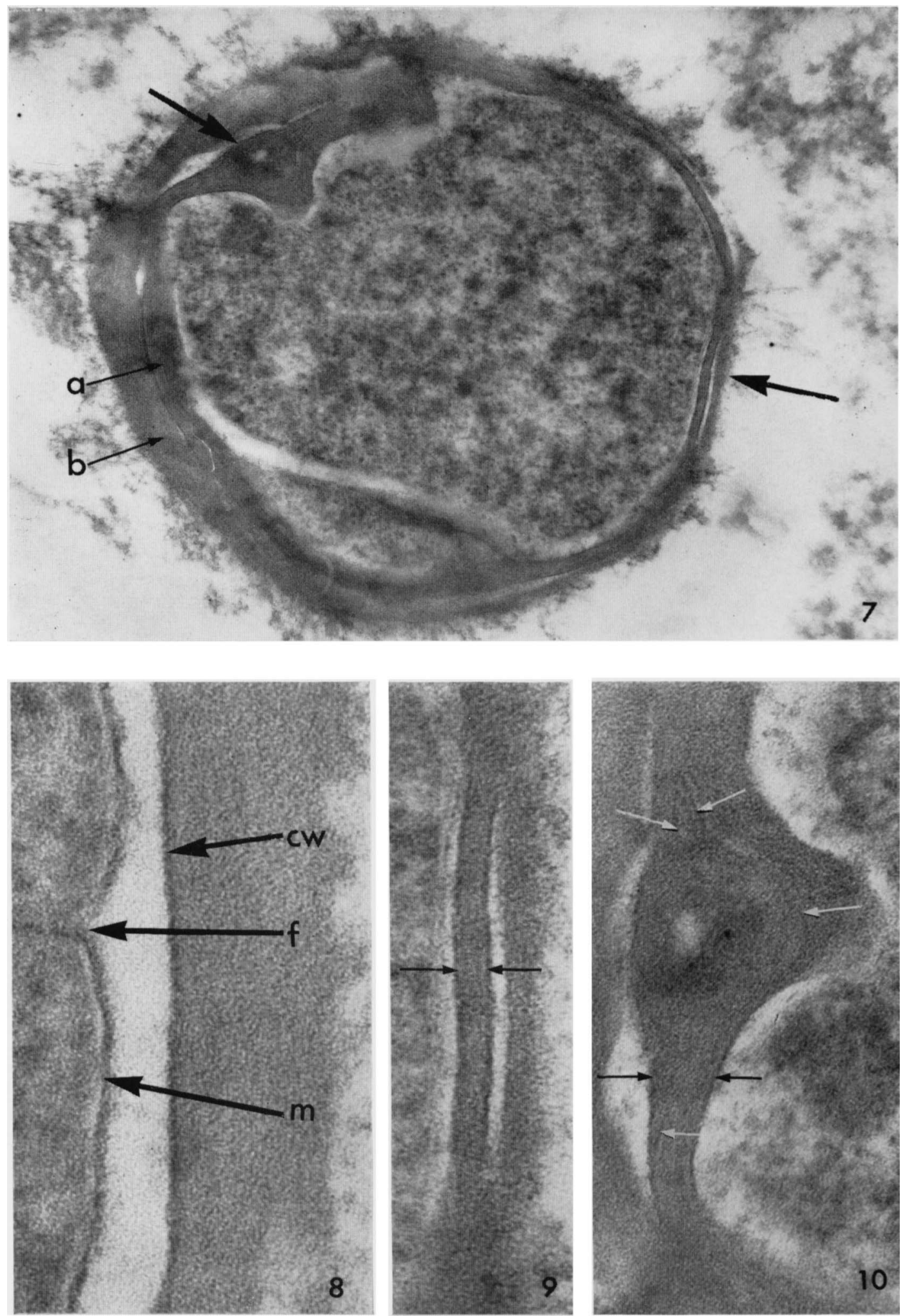

H. J. ROGERS, M. McCONNELL AND I. D. J. BURDETT 
Journal of General Microbiology, Vol. 61, No. 2

Plate 5
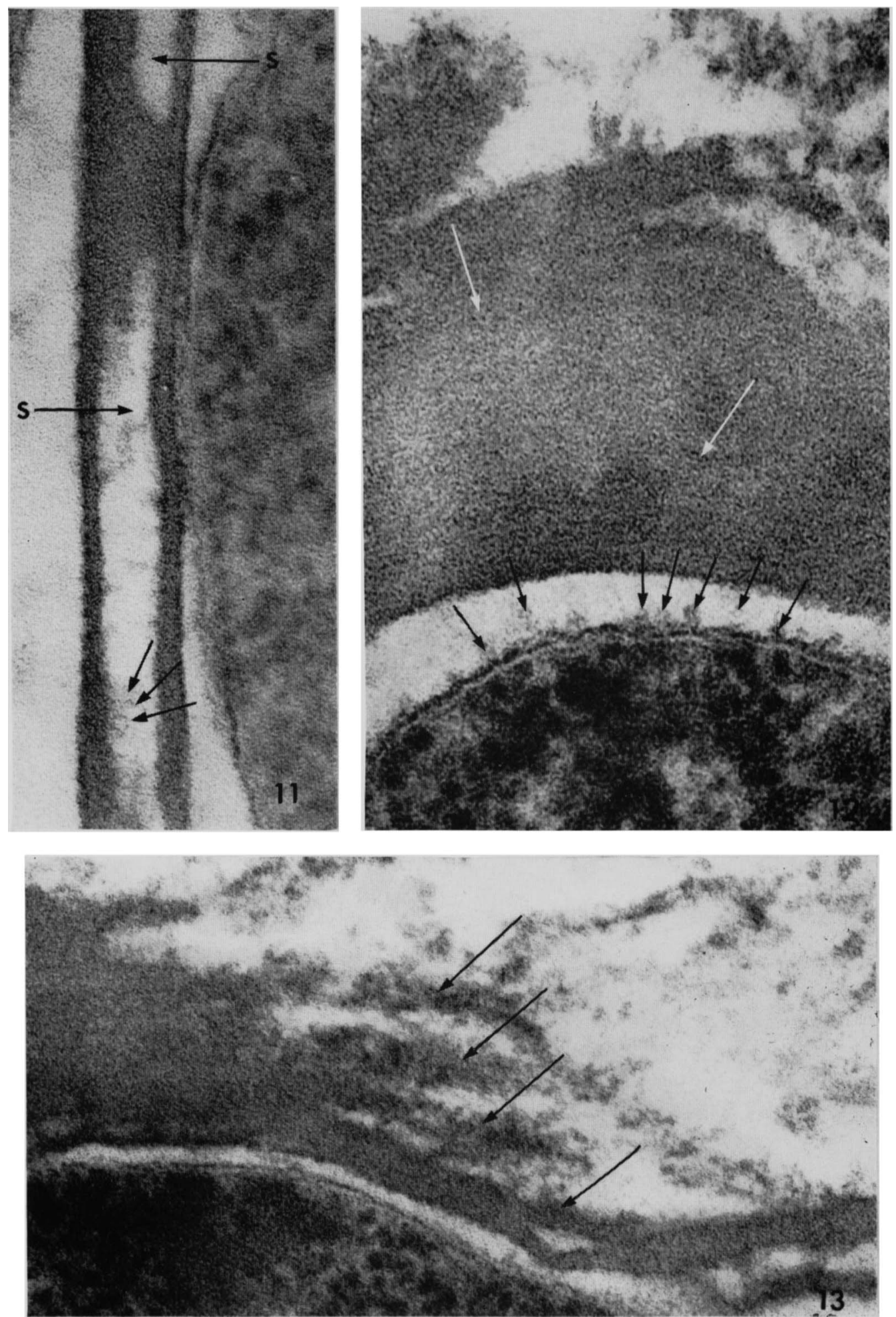

H. J. ROGERS, M. McCONNELL AND I. D. J. BURDETT 
Journal of General Microbiology, Vol. 6I, No. 2

Plate 6
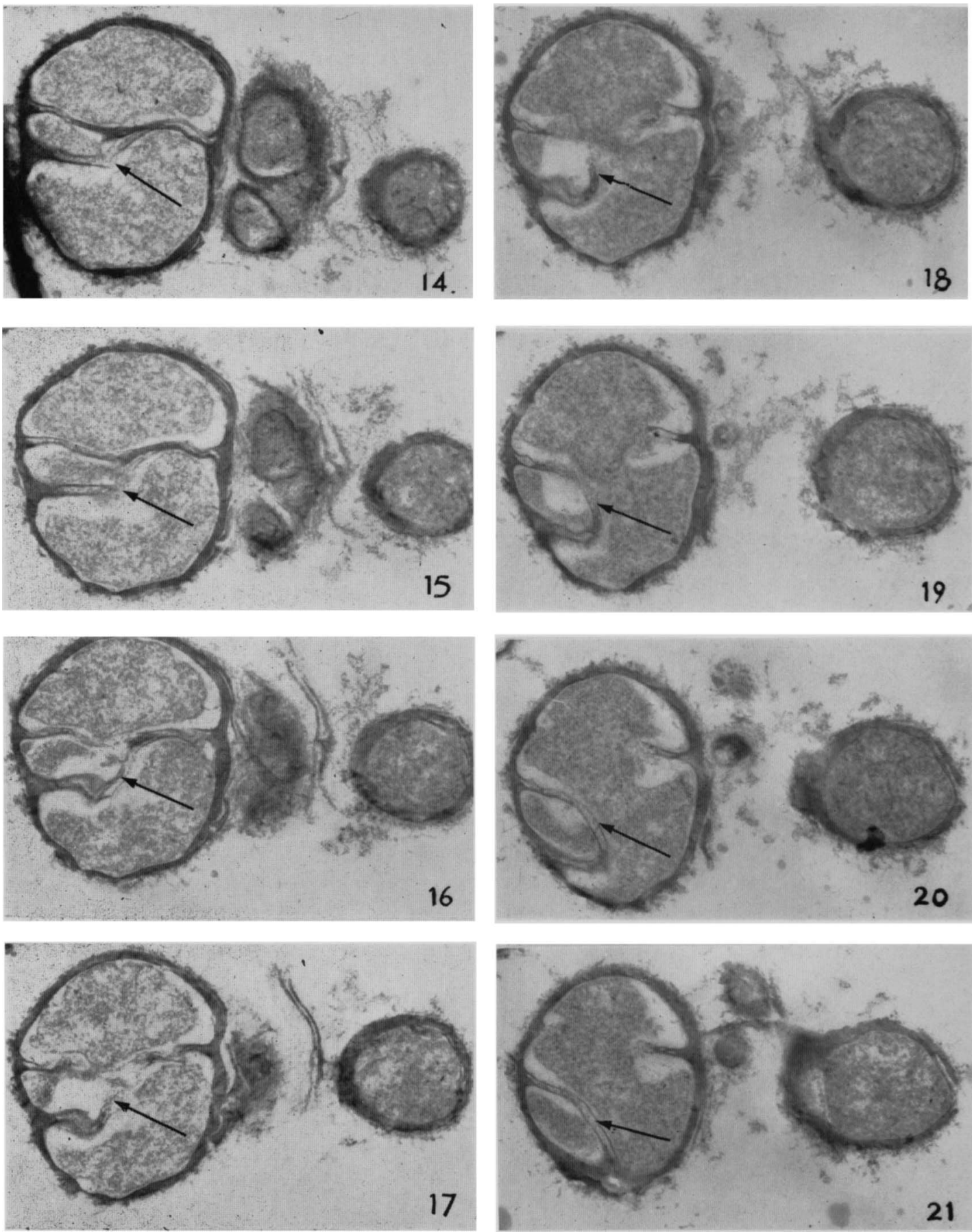

H. J. ROGERS, M. McCONNELL AND I. D. J. BURDETT 
Journal of General Microbiology, Vol. 6I, No. 2

Plate 7
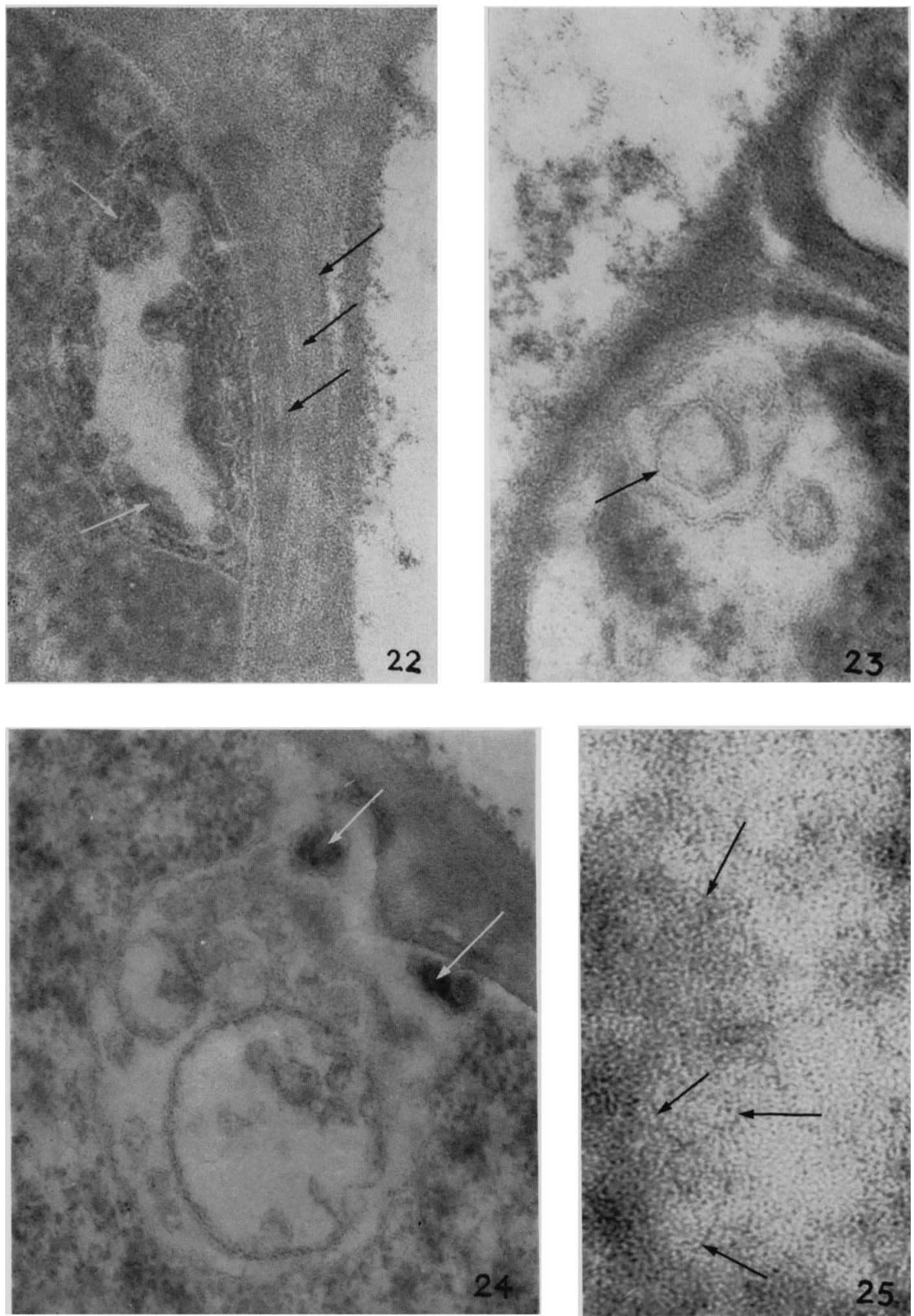

H. J. ROGERS, M. MCCONNELL AND I. D. J. BURDETT 
Journal of General Microbiology, Vol. 61, No. 2

Plate 8
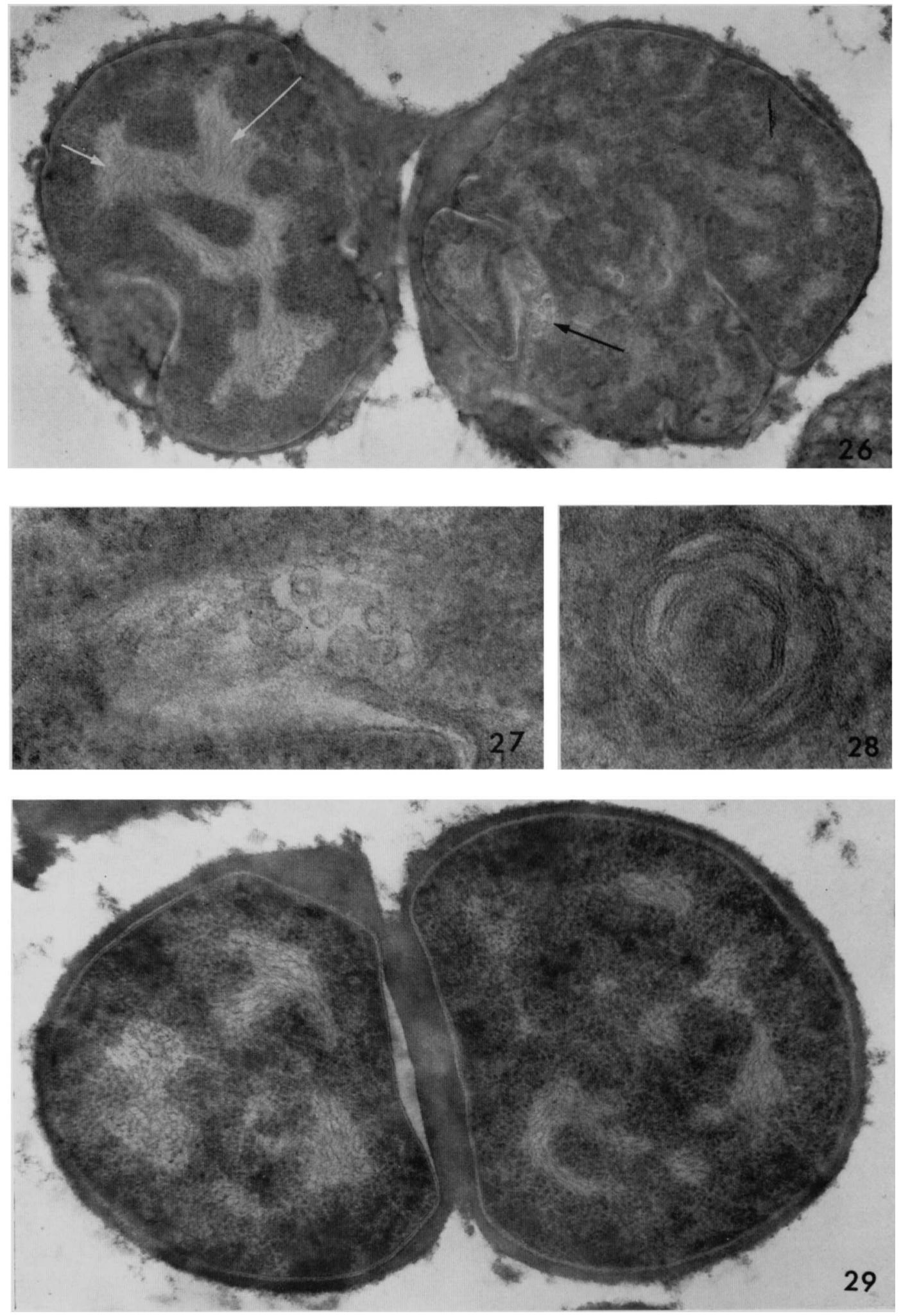

H. J. ROGERS, M. McCONNELL AND I. D. J. BURDETT 
Journal of General Microbiology, Vol. 6I, No. 2

Plate 9
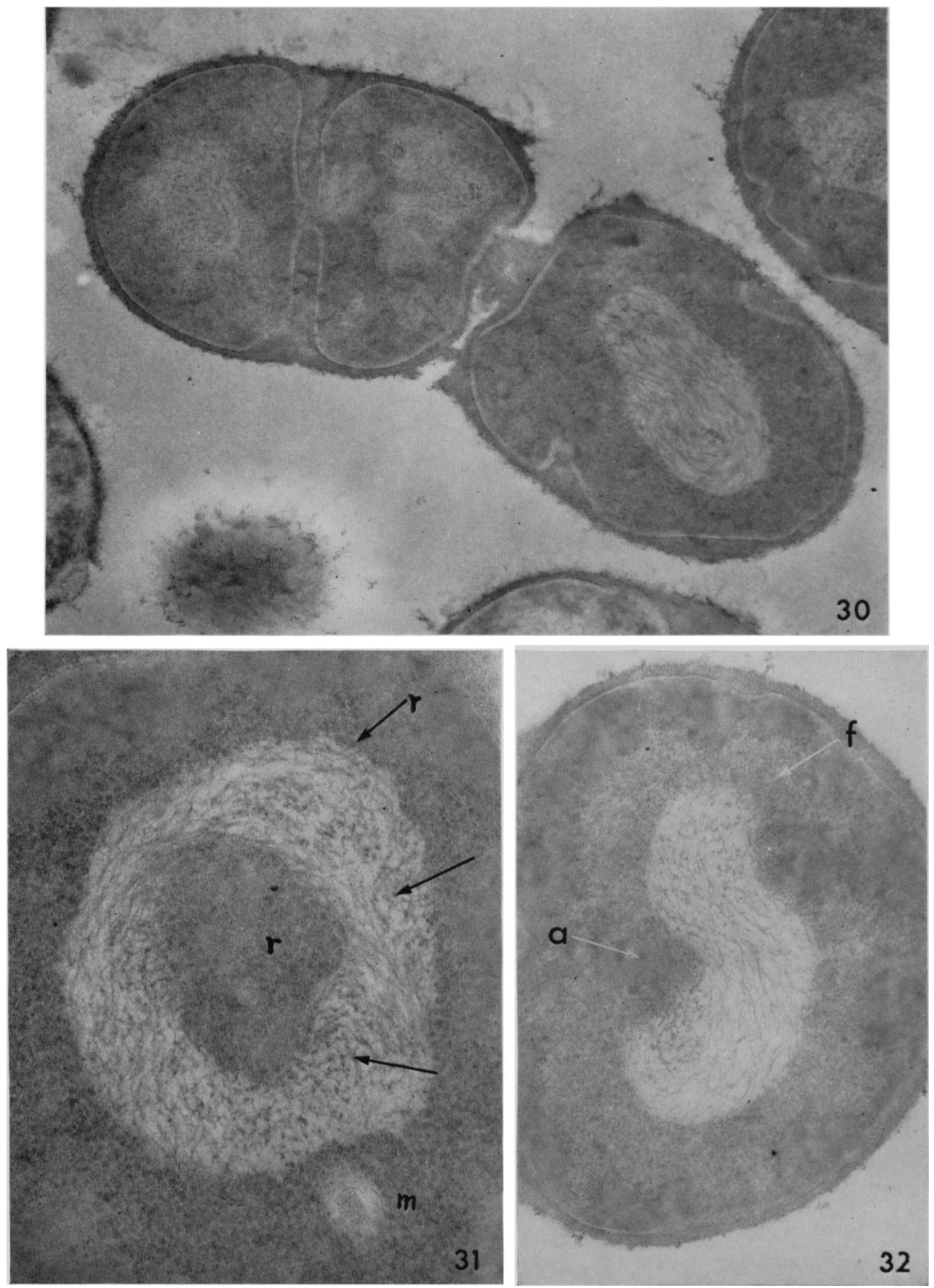

H. J. ROGERS, M. McCONNELL AND I. D. J. BURDETT 
Journal of General Microbiology, Vol. 6I, No. 2

Plate Io
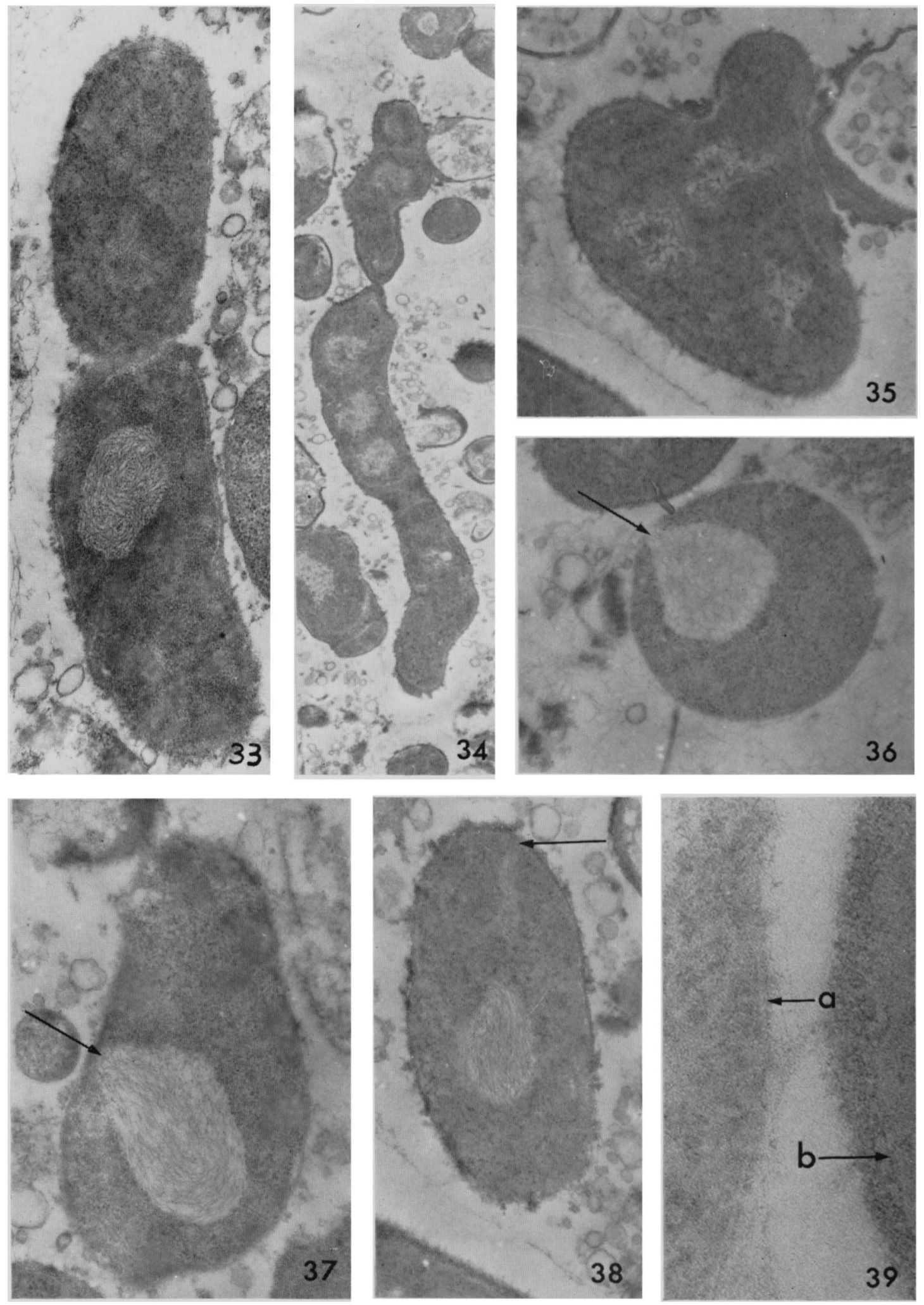

H. J. ROGERS, M. McCONNELL AND I. D. J. BURDETT 
Journal of General Microbiology, Vol. 6r, No. 2

Plate II
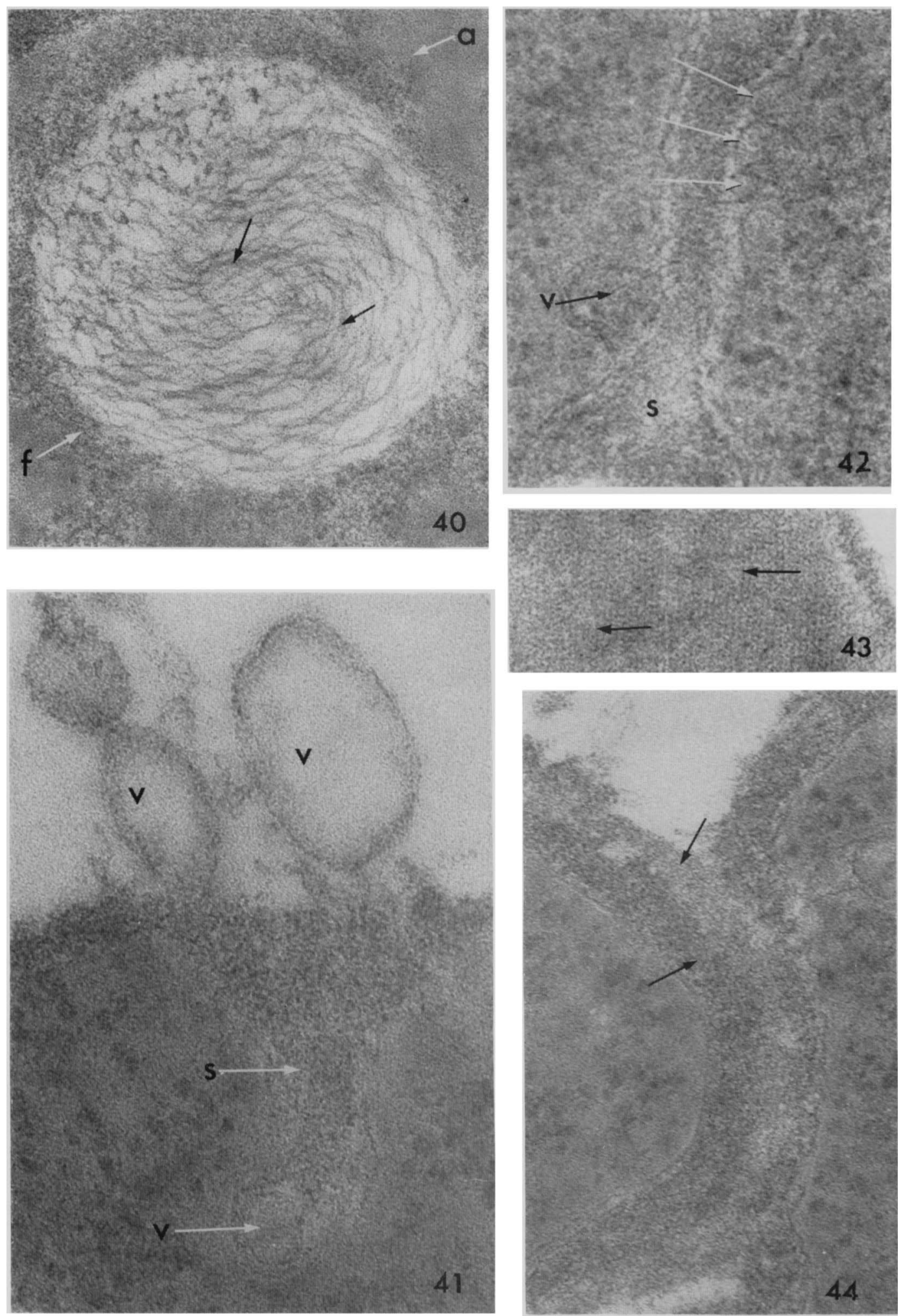

H. J. ROGERS, M. McCONNELL AND I. D. J. BURDETT 
Journal of General Microbiology, Vol. 6I, No. 2

Plate 12
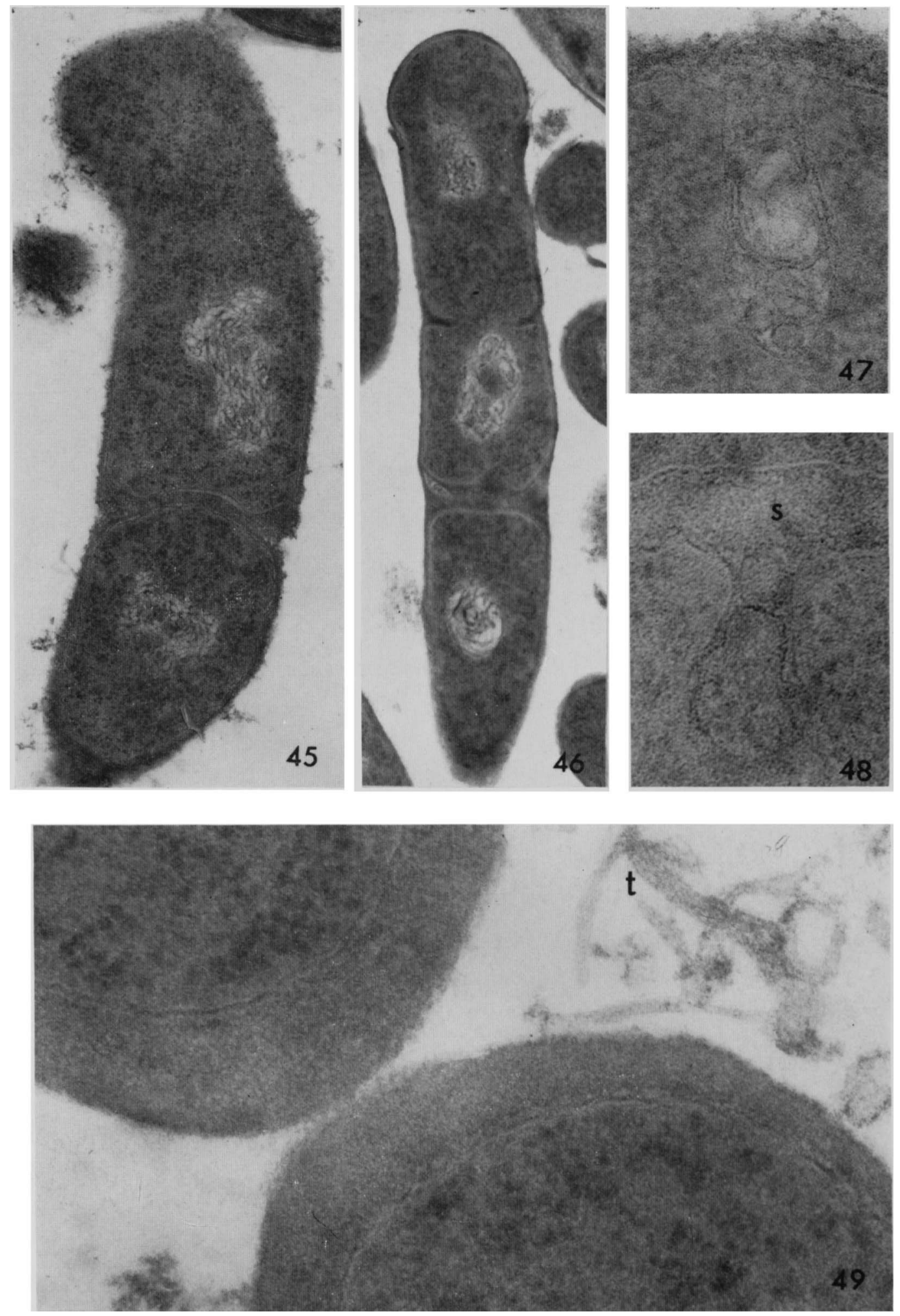

H. J. ROGERS M. MCCONNELL AND I. D. J. BURDETT 
Fig. 42. Section of a septum (s) showing infoldings of cytoplasmic membrane as vesicles (v) or as protrusions (white arrows). The vesicle contains material of similar density to the septum. Note thickened base of septum. $\times 176,000$.

Fig. 43. Section of a crystalline region showing a marked periodicity (arrows). $\times$ I 76,000.

Fig. 44. Section of a septum separating a pair of dividing organisms; septum composed of two zones of different density (arrows). × I69,000.

\section{Plate I2}

Mutant rod-4 grown in $0.8 \mathrm{M}-\mathrm{NaCl}$ (fig. 48) and I M-NaCl (fig. 45 to 47,49 ).

Fig. 45 to 46 . Rod-shaped organisms with thickened septa and highly condensed nuclei. $\times 42,809$; $\times 27,242$.

Fig. 47. Mesosome-like structure consisting of large vesicles within an infolding of the cytoplasmic membrane. $\times 135,200$.

Fig. 48. Vesicular structures within an infolding of cytoplasmic membrane and in association with a septum (s). $\times 174,766$.

Fig. 49. Section of thickened walls between a pair of organisms; associated with the organisms are tubular and vesicular membranes $(t) . \times 157,316$. 